\section{E-LOGOS}

ELECTRONIC JOURNAL FOR PHILOSOPHY ISSN 1211-0442

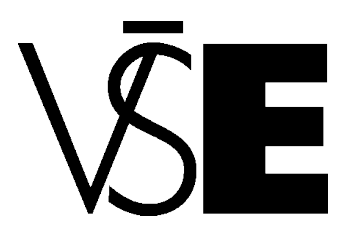

University of Economics

Prague

\title{
Časopriestorová lokalizácia vesmírnych civilizácií
}

Robert Burgan

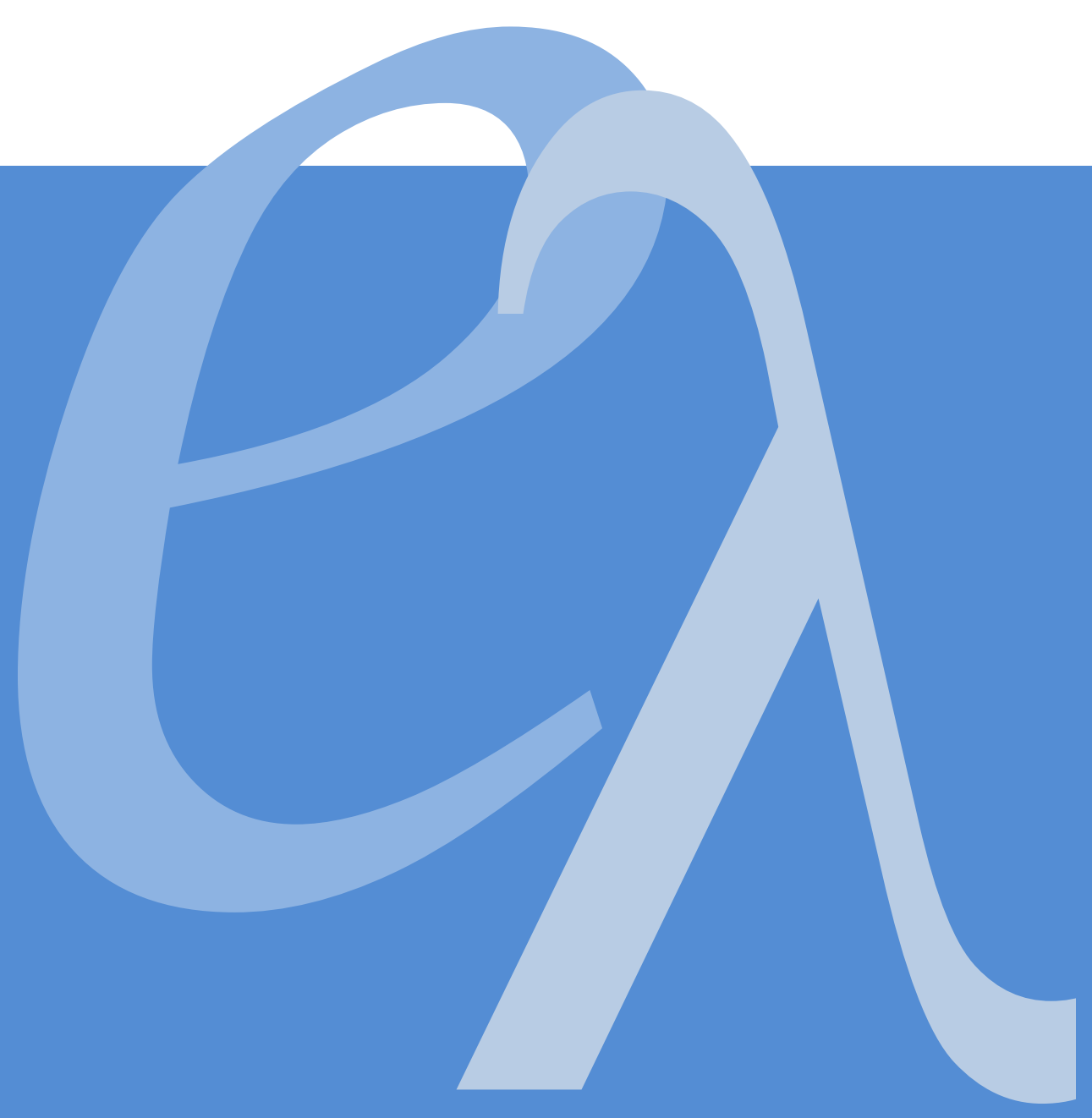




\begin{abstract}
In the first part of this paper we discuss the conditions and circumstances under which extraterrestrial civilisations probably emerge in the universe; finding-out that extraterrestrial civilisations of a type known to us (i.e. humanoid) emerge only in certain localities of our universe where they exist only to a certain time depending on pre-given and ever changing local and later global conditions of existence. In the second part we focus more on internal existence limits of extraterrestrial civilisations that are as specific forms or specific realizations of social form of matter motion determined and influenced by specific parameters of people as its basic structural or substantial elements as well as by specific social-economic laws that bind these elements to each other up to the moment when the social form of matter motion is replaced by completely new super-social form of matter motion that will come on evolution "scene" with its own structural elements, movement and reproduction laws and thus also with own evolutional trajectories and destinies.
\end{abstract}

Key words: extraterrestrial civilisations, green belt, Fermi's paradox, social form of matter motion, technological singularity, super-social form of matter motion, development in the universe.

\begin{abstract}
Abstrakt
V prvej časti tohto príspevku diskutujeme o podmienkach a okolnostiach, za akých vesmírne civilizácie pravdepodobne vo vesmíre vznikajú, zist'ujúc, že vesmírne civilizácie nám známeho (t. j. humanoidného) typu vznikajú len v určitých lokalitách nášho vesmíru, kde zároveň existujú len do určitého času, v závislosti od dopredu daných a zároveň sa sústavne meniacich lokálnych a neskôr aj globálnych existenčných podmienok. $V$ druhej časti si viac všímame vnútorné existenčné limity vesmírnych civilizácií, ktoré sú ako zvláštne formy či konkrétne realizácie sociálnej formy pohybu hmoty určené a ovplyvnené práve špecifickými parametrami l'udí ako svojich základných, štruktúrnych alebo substanciálnych prvkov, ako aj špecifickými sociálno-ekonomickými zákonmi, ktoré tieto prvky viažu k sebe navzájom až do toho momentu, kým namiesto sociálnej formy pohybu hmoty nevstúpi na evolučnú "scénu“ úplne nová, nadsociálna forma pohybu hmoty aj so svojimi vlastnými štruktúrnymi prvkami, pohybovými a reprodukčnými zákonmi a tak aj vlastnými evolučnými trajektóriami a osudmi.
\end{abstract}

Klíčová slova: vesmírne civilizácie, zelený pás, Fermiho paradox, sociálna forma pohybu hmoty, technologická singularita, nadsociálna forma pohybu hmoty, vývoj vo vesmíre. 


\section{Úvod1}

Hned' potom ako zvedaví pozemšt'ania vd'aka P. Morrisonovi a G. Cocconimu v roku 1959 zistili (Dick, 2004, s. 251-253), že rádiové vlny sa dajú využit' aj na niečo úplne iné ako len prenášanie "chytl'avých“ hitov do uší nudiacich sa poslucháčov, t. j. na prenášanie informácií od jednej hviezdy či extrasolárnej planéty k druhej, a to na frekvenčnom štandarde emisnej čiary neutrálneho vodíka (s vlnovou dížkou $21 \mathrm{~cm}$ ), takmer okamžite otočili obrovské "uchá" svojich rádioteleskopov smerom k najpodozrivejším (t. j. najbližším a Slnku najpodobnejším) hviezdam s nádejou, že prípadní vesmírni „susedia“ uvažujú podobne ako oni a pretože sú bezpochyby ovel'a starší, múdrejší a bohatší, určite už dokážu vysielat' na medzihviezdne vzdialenosti natol'ko často a intenzívne, že by sa ich správy mohli dat' zachytit' na dostatočne citlivých rádioteleskopoch, potom dešifrovat' a vzápätí využit' pri vylepšovaní ich životných podmienok, s ktorými pozemštania nikdy nie sú spokojní, alebo pochopit' ako počiatočný impulz ku komunikácii, ktorá obidvom civilizáciám pomôže prekonat' ich „druhocentrizmus“. Bohužial”, ani desat'ročia "načúvania“ očividne neviedli k žiadnemu kladnému výsledku, a tak pozemštania začali pre zmenu špekulovat' nad tým, prečo je to tak a prečo ich nikto nechce.

Bolo predložených obrovské množstvo vysvetlení (len S. Webb (2002) ich napríklad predkladá presne 50), ale pre pozemšt'anov je typické, že si nakoniec vybrali riešenie, ktoré sa zdá svedčit' v prospech ich výnimočnosti, čiže riešenie, ktoré je implicitne prítomné v rámci úvah o tzv. Fermiho paradoxe. Slávny taliansky fyzik totiž pät' rokov po tom, ako pomohol spolu s d'alšími svojimi kolegami rozsvietit' nad Hirošimou a Nagasaki obrovské „lampióny“, z ktorých žiarenia sa mnohí Japonci dodnes nespamätali, položil priamo v Los Alamos svojim kolegom (Dick, 2004, s. 269) trochu zlostnú otázku: „Ak existujú mimozemštania, kde teda sú?“ Po krátkom čase sa ale ukázalo, že to nebola otázka, ale odpoved', pretože na jej základe (alebo v jej konceptuálnom rámci) napríklad M. Hart a D. Viewing tvrdili (1975), že žiadni mimozemšt́ania neexistujú, pretože ak by v našej galaxii existovali len o niečo vyspelejšie civilizácie ako je naša, už by aj pri relatívne nízkej rýchlosti svojich hviezdnych lodí bud' osídlili a kolonizovali, alebo aspoň preskúmali našu galaxiu, vrátane nami obývanej Slnečnej sústavy; čo ale nepozorujeme, a tak je najrozumnejšie celú túto diskusiu uzavriet' poznámkou, že sme v Galaxii sami a „načúvat" mimozemským rádiovým signálom je teda úplne zbytočné.

Rovnako by sme ale mohli namietnut', že v súčasnosti vieme príliš málo o distribúcii vesmírnych civilizácií (či nám známeho typu života) v jednotlivých častiach našej galaxie či dokonca v pozorovanom vesmíre ako takom (ako naznačujú Webbove riešenia č. 9, 10, 11, 34-49 a i.), a ešte menej o evolučných trajektóriách

${ }^{1}$ Tento text o vesmírnych civilizáciách vychádza súčasne v zborníku Fyzika a etika VII Univerzity Konštantína Filozofa v Nitre. 
samotnej našej civilizácie, ktorá sa ako taká (spolu s nami pozemšt́anmi ako svojimi základnými štruktúrnymi alebo substanciálnymi prvkami) môže onedlho zmenit' (čo sú Webbove riešenia č. 26 a 28) na nadsociálnu formu pohybu hmoty (d'alej aj FPH), a to spôsobom, ktorý si dnes nedokážeme ani len predstavit', pričom takáto FPH nebude javit' žiadny záujem o komunikáciu s nami, najmä ak jej "prvky“ budú interagovat’ na podstatne „humánnejšej“ úrovni, t. j. bez toho, aby sa navzájom prznili, vraždili, mučili, klamali, manipulovali, okrádali či len ohovárali. Pravdaže, pre zástancov idey o večnosti alebo nezmenitel'nosti l'udskej biologickej prirodzenosti (či podstaty) sú a budú všetky úvahy o nadsociálnom len sterilnými či dokonca nebezpečnými špekuláciami, ale nám filozofom predsa nič nebráni, aby sme sa dôsledne zamysleli nad tým, kde sa momentálne asi nachádzajú naši vesmírni „bratia“ a čo by mohlo byt” to ovel’a lepšie, čo nás raz určite nahradí.

\section{Vesmírne civilizácie sa nachádzajú len v niektorých lokalitách nášho vesmíru}

Z hl'adiska každej vesmírnej civilizácie je dôležité najprv vediet', aké je stabilné či "trvanlivé" prostredie, v ktorom sa nachádza avktorom realizuje svoje aktivity. V najširšom slova zmysle je pre nás takýmto prostredím nami pozorovaný a obývaný vesmír, na ktorého stabilitu, resp. „trvanlivost" však existujú tie najrôznejšie názory. Ako vie každý čitatel' dnes tak populárnej kozmologickej literatúry (Davies, 1994; Greene, 2001; Singh, 2007; Vilenkin, 2008 a i.), až donedávna sa diskutovalo najmä o tom, či je vesmír statický, tak ako v 50. rokoch minulého hlásali Bondi, Hoyle, Gold a iní, v tom zmysle, že nevzniká, ale existuje večne, pričom si v podstate zachováva ten istý fyzikálny obsah (a to aj v prípade, že sa rozpína a tzv. C-pole v ňom neustále generuje novú hmotu; Sánchez-Ron, 1990, s. 240), alebo dynamický a teda aj historický (alebo vyvijajúci sa) v tom zmysle, že vzniká pred určitým časovým intervalom, počas svojho rozpínania sa prinajmenšom kvantitatíune mení (čiže rastie) a v závislosti od pomeru jeho reálnej hustoty $\mathrm{k}$ tzv. kritickej hustote označovanej písmenom omega $(\Omega)$ v troch štandardných scenároch (Horský et al., 2004, s. 64-70) pri nižšej ako kritickej hustote (alebo zápornej krivosti $k=-1$ ) najprv expanduje večne (podl'a všetkého konštantnou rýchlost'ou).

Pri hustote, ktorá sa viac-menej rovná kritickej (kedy $k=0$ ), expanduje takisto večne, ale čoraz pomalšie, resp. decelerovane, zatial' čo pri nadkritickej hustote (kedy $k=+1)$ skôr či neskôr dospeje do štádia, kedy sa jeho expanzia zastaví a vesmír sa začne zmršt'ovat', podl'a všetkého až do tzv. záverečnej singularity (akéhosi bodového "stavu“ s nulovým objemom, nekonečnou teplotou a hustotou). Koncom 80. rokov sa však začala čoraz viac presadzovat’ tzv. inflačná kozmológia, ktorá tvrdí, že dokáže vyriešit' všetky problémy tzv. štandardného relativistického modelu aj s jeho tromi vyššie uvedenými scenármi, v rámci ktorej (Linde, 1990) síce nebola úplne zavrhnutá idea vel'kého tresku a vzniku nášho vesmíru z počiatočnej 
singularity, ale ovel'a dôležitejší sa stal samotný inflačný mechanizmus, pomocou ktorého sa opakovane produkujú alebo generujú nové inflačné vesmíry. V určitom „priblížení“ môžeme dokonca konštatovat', že inflačná kozmológia akoby „vdýchla nový život“ statickému modelu vesmíru, ked’ Linde et al. (1993) predložili svoj model stacionárneho inflačného vesmíru, v ktorom sa čast' jeho hmoto-energie rozpína večne pri limitnej planckovskej hustote (zhruba $5 \times 10^{96} \mathrm{~kg} \mathrm{~m}^{-3}$ ), d'alšia prekračuje túto hustotu a okamžite sa zmršt́uje do tzv. čiernych dier.

No a zvyšok sa rozpína v rámci niektorého $\mathrm{z}$ troch vyššie uvedených kozmologických scenárov bud' večne, alebo po niekol'kých desiatkach miliárd rokov kolabuje do singularity. V 90. rokoch minulého storočia sa zároveň začali objavovat' a čoraz viac presadzovat' aj tzv. strunové kozmologické modely či teórie (podl'a ktorých sa na najspodnejšej úrovni fyzikálnej reality nenachádzajú všeobecne známe elementárne častice, ako sú kvarky, leptóny či fotóny, ale maličké, neustále vibrujúce a navzájom sa spájajúce i rozdelujúce struny či membrány), v ktorých už bola definitívne zavrhnutá idea vel'kého tresku i samotnej singularity na počiatku nášho vesmíru. Podl'a Steinhardta a Turoka (2009, s. 72 a n.) napríklad celý (multi)vesmír pozostáva zdvoch opakovane sa zrážajúcich 3-dimenzionálnych membrán, umiestnených v 4--dimenzionálnom priestore Hořavovej a Wittenovej membránovej teórie, ktoré sa po väčšinu času exponenciálne rozpínajú, ale akonáhle sa vyčerpá kinetická energia kvintesenčného pol'a (ktoré dovtedy poháňalo ich expanziu), začnú sa k sebe približovat', aby sa nakoniec zrazili počas fyzikálneho procesu, ktorý sa vel'mi podobá vel'kému tresku (VT), pretože aj počas neho sa ustanovuje 4dimenzionalita d'alšieho vesmíru a vznikajú nové elementárne častice. ${ }^{2}$

S d’alším vel'mi zaujímavým strunovým kozmologickým modelom prišli Brandenberger s Vafom (in Greene, 2001, s. 224-225), podl'a ktorých je takisto vesmír cyklický, a to kvôli existencii tzv. l'ahkých a t’ažkých strunových vibračných módov, ktoré vraj zabezpečujú, že namiesto tzv. vel'kého krachu (alebo zmrštenia sa vesmíru do „bodu“ s nulovým objemom) sa tento môže zmrštit” maximálne do vel'kosti Planckovej dížky (zhruba 1,6 x 10-35 m) a z tohto stavu odrazit' do d'alšej expanzívnej fázy. Skutočným šokom však bol až objav zrýchleného vesmírneho rozpínania, ku ktorému dospeli dva výskumné tímy (Perlmutterov a Riessov, in Kirshner, 2005) v roku 1998. Pri meraní najvzdialenejších supernov typu Ia totiž obidva tímy zistili,

\footnotetext{
${ }^{2}$ Aj ked' s tou dôležitou odlišnost'ou, že takýto VT možno jednoznačne vymedzit' ako v čase prebiehajúci fyzikálny proces, realizujúci sa pri teplote asi $10^{27}$ kelvina, pričom odpadá aj problém so sústavne rastúcou entropiou (a tak aj rozmermi jednotlivých po sebe nasledujúcich vesmírov), pretože počas približovania sa obidvoch membrán síce stále rastie celková entropia, ale vd’aka zvinovaniu sa dodatočnej štvrtej priestorovej dimenzie v jednotlivých cykloch rastie a klesá celková hustota entropie. Vo vzt’ahu k takto vymedzenému VT, ktorý niektorí autori dokonca priamo stotožňujú s počiatočnou singularitou (Grygar, 1997, s. 97), tak môžu Steinhardt s Turokom nakoniec konštatovat' (Steinhardt - Turok, 2009, s. 73), že obdobia pred ním a po ňom „sú však prepojené hladko, štruktúra priestoru zostane nedotknutá, energia je všade konečná a čas ubieha spojito“; čo je pravdaže v zjavnom rozpore s dovtedy prevládajúcimi predstavami, podla ktorých nemá zmysel uvažovat' o čase a priestore pred VT, ktorý ale pri takomto prístupe predstavuje de facto nefyzikálny fenomén či anomáliu.
} 
že sa nachádzajú ovel’a d'alej, ako by sa mali v nachádzat' v prípade, že sa náš vesmír spočiatku rozpínal spomalene, a čo je nemenej dôležité, d'alšie merania červeného posunu supernov aj v menších vzdialenostiach definitívne potvrdili, že sa vesmír od určitého času rozpína stále rýchlejšie. $\mathrm{V}$ dôsledku toho sa znovu a tentoraz už zrejme navždy vrátila do kozmológie Einsteinova kozmologická konštanta $\Lambda$, počítajúca so skrytou či tmavou energiou fyzikálneho vákua, ktorá zrejme zapríčiňuje toto zrýchlené rozpínanie sa (nášho) vesmíru.

V rokoch 2002 až 2003 potom na základe týchto meraní, ako aj na základe čoraz presnejších a detailnejších meraní fyzikálnych parametrov mikrovlnného žiarenia vesmírneho pozadia (angl. cosmic microwave background radiation, CMBR), realizovaných pomocou dnes už legendárnych satelitov COBE a WAMP, kozmológovia vypracovali nový štandardný kozmologický model (Freedmanová, 2002; Freedmanová - Turner, 2003; Spergel, 2003 a i.), ktorý už zohladňoval existenciu nielen tmavej energie (fyzikálneho vákua), ale aj tzv. tmavej hmoty, pričom tieto „ingrediencie“ tvorili podstatnú čast' jeho hmoto-energetického obsahu, konkrétne (Freedmanová - Turner, 2003, s. 20-22, 36) - tmavá energia $67 \pm 6 \%$, studená tmavá hmota (zrejme len gravitačne interagujúca s obyčajnou, baryónovou látkou) $29 \pm 4 \%$; čo prirodzene podnietilo viacerých bádatel'ov k úvahám nad fyzikálnou podstatou či budúcim správaním tmavej energie (ktorá by mala v budúcnosti dominovat' vesmírnemu rozpínaniu), vrátane nami už diskutovaného (Burgan, 2012a, s. 19) Caldwellovho et al. scenára, podl'a ktorého tzv. fantómová energia, ktorej hustota s časom rastie, roztrhá už o niekol'ko miliárd rokov nielen galaxie, hviezdy a planéty, ale možno aj všetky nukleóny a elementárne častice.

Rovnako hrozivo, ak nie ešte hrozivejšie, vyznievajú scenáre, ktoré predložili už v roku 1980 S. Coleman s F. de Lucciom (in Davies, 1994, s. 138 a n.), podl'a ktorých sa fakticky kedykol'vek môže stat', že náš vesmír prejde z energeticky ovel'a vyššieho vákuového stavu do nižšieho, v dôsledku čoho sa bublinka pravého vákua (tamže, s. 141-142) začne rozpínat' takmer svetelnou rýchlost'ou a pohlcovat' oblast' falošného vákua vrátane nás samotných, až kým sa vnútro ňou pohltenej oblasti nezrúti aj s nami do časopriestorovej singularity; a tak je len prirodzené, že sa čoskoro objavili štúdie, a to aj od vel'mi renomovaných kozmológov, ktorých autori sa snažili zachránit' ak aj nie celé l'udstvo (či našu civilizáciu), tak aspoň náš kultúrny odkaz, ako napríklad J. Garriga et al. (2000), ktorí špekulovali nad skonštruovaním „kontajnerov“ zo špeciálnej hmoty, do ktorých by bola uložená informácia, pomocou ktorej by bolo možné aspoň sčasti zrekonštruovat' v d'alšom vesmíre pozemskú civilizáciu a vytvorit' tak nekonečný a sústavne sa zdokonalujúci civilizačný rad. V tomto momente sa nám však všetky podobné špekulácie zdajú značne predčasné, pretože len málo kozmológov považuje Caldwellom et al. (2003) predloženú stavovú rovnicu nášho vesmíru s $w<-1$ za realistickú. 
A navyše, uvažovat' o prechode $\mathrm{z}$ falošného vákua do pravého vákua $\mathrm{v}$ našom vesmíre bude podl'a nás namieste až vtedy, ked' dôjde k výraznej dezaktualizácii jeho fyzikálneho obsahu (t. j. rozpadu gravitačne viazaných sústav a možno aj väčšiny elementárnych častíc), k čomu však vo väčšine kozmologických modelov dôjde až o niekol'ko desiatok miliárd či dokonca biliónov rokov. Preto budeme d'alej považovat' (náš) vesmír jednoducho za daný, aj ked' vzhl'adom na jeho sústavne sa meniaci fyzikálny obsah nie rovnako vhodný pre vznik a zrýchlený vývin vesmírnych civilizácií, pretože gravitačne viazané sústavy, v rámci ktorých je možné akumulovat' a skladovat' vol'né informácie, v ňom podl'a všetkého budú existovat' (pokial' počítame so scenárom večne sa rozpínajúceho vesmíru) len dovtedy, kým nedôjde k masívnej evaporácii čiernych dier (aj ked’ tie budú podl'a Daviesa (1994, s. 100) v závislosti od svojej vel'kosti explodovat' až o hrozivých $10^{66}$ a viac rokov). Skôr však, ako definitívne prejdeme k vymedzeniu lokalít, vktorých spontánne vznikajú a niekol'ko sto až tisíc rokov existujú vesmírne civilizácie, musíme uviest' vel'mi dôležitú metodologickú poznámku, ktorej ignorovanie často vyúst'uje do skreslených odhadov ich faktickej distribúcie (či lokalizácie).

Ako je totiž známe, časopriestorová distribúcia a nakoniec aj lokalizácia vesmírnych civilizácií sa odhaduje a/lebo vypočítava na základe Drakeovej rovnice, ktorú tento americký rádioastronóm predložil svojim kolegom prvý raz na posúdenie (Dick, 2004, s. 258) v roku 1961 na konferencii o medzihviezdnej komunikácii v Green Banku, pričom pri dosadzovaní číselných hodnôt do tejto rovnice $^{3}$ sa už vtedy začali preferovat' dva typicky pozemsky naivné a jednostranné prístupy, kedy jedna skupina bádatel'ov, snažiaca sa presvedčit' daňových poplatníkov o zmysluplnosti svojho správania, zrejme podvedome nadhodnocovala jednotlivé "položky“ Drakeovej rovnice, aby na konci vyšla čo najoyššia hodnota $N$ a tým pádom aj čo najvyšší počet komunikabilných civilizácií v Galaxii (pri dostatočnej hustote ktorých má vôbec zmysel vysielat' na správy na obrovské medzihviezdne vzdialenosti), zatial' čo druhá skupina, skalopevne presvedčená o l'udskej výnimočnosti, sa naopak snažila číselné hodnoty týchto "položiek" čo najviac zredukovat' alebo znížit', dochádzajúc nakoniec k záveru, že je vel'mi pravdepodobné, že na l'avej strane Drakeovej rovnice je číslo 1, reprezentujúce práve našu (vel'mi často Bohom vyvolenú alebo výnimočne obdarenú) komunitu (či modrú planétu).

\footnotetext{
${ }^{3} \mathrm{~N}=\mathrm{R}^{*} f_{p} n_{e} f_{l} f_{i} f_{c} L$; v ktorej $\mathrm{N}$ označuje (Dick, 2004, s. 259) celkový počet aktuálne komunikujúcich alebo komunikácie schopných vesmírnych civilizácií v Galaxii, zatial' čo pravá čast' zahrňuje faktory (alebo činitele), ktoré vedú k upresneniu ich celkového počtu, kedy $\mathrm{R}^{*}$ označuje „astronomický odhad rýchlosti vzniku hviezd““ v Galaxii (alebo ako trochu priamočiarejšie, ale aj ovel'a nepresnejšie píše Sagan (1998, s. 298), „počet hviezd v Mliečnej dráhe" $), f_{p}$ podiel hviezd s planetárnymi sústavami, $n_{e}$ počet biogénnych alebo obývatel'ných planét $\mathrm{v}$ danej planetárnej sústave, $f_{l}$ podiel planét skutočne disponujúcich živými systémami, $f_{i}$ podiel planét $\mathrm{s}$ tzv. inteligentným životom, $f_{c}$ podiel planét s komunikabilnými civilizáciami a $L$ dobu života takýchto civilizácií.
} 
Už v roku 1979 však L. Gindilis a B. Panovkin odmietli všetky tendenčné prístupy, v rámci ktorých sa do Drakeovej rovnice pridávajú d'alšie a d'alšie faktory (alebo "položky“), v dôsledku čoho sa čoraz viac znižuje pravdepodobnost' spontánneho vzniku komunikabilnej civilizácie, naznačujúc zároveň, že ovel'a inteligentnejší a korektnejší je prístup, pri ktorom sa dané faktory nechápu ako redukujúce (výskyt komunikabilných civilizácií), ale ako faktory limitujúce, t. j. bližšie určujúce, za akých podmienok (alebo okolností) vesmírne civilizácie spontánne vznikajú a pretrvávajú až do momentu, dovolíme si doplnit', kým nezaniknú alebo nie sú vystriedané nejakou vyššou, t. j. nadsociálnou FPH. Z tohto uhla pohl'adu preto treba podl'a nás posudzovat' aj nasledujúcu diskusiu o lokalizácii vesmírnych civilizácii (d’alej aj VC) v našom vesmíre, v ktorej budeme vychádzat' z Taylerových (1981), Gonzalesových et al. (2002) a Wardových a Brownleeho textov (2003a, 2003b), konštatujúc hned' na úvod, že ak budeme chápat' vesmírnu vývinovú trajektóriu, ktorá viedla k vzniku nášho druhu a našej komunikabilnej vesmírnej civilizácie za typickú alebo väčšinovú ${ }^{4}$, potom okamžite zistíme, že takéto civilizácie spontánne vznikajú len v určitých vývojových fázach tzv. špirálových galaxií.

Aj po zohl'adnení tzv. evolučných vplyvov (t. j. zrážok galaxií a s tým spojených zmien ich tvaru i fyzikálneho obsahu, vyplývajúcich z toho, že homogénnost' a izotropnost' vesmíru sa prejavuje až na vel'kostnej škále asi 200 miliónov svetelných rokov; Rees, 2002, s. 74) teda možno konštatovat' (Tayler, 1981; Gonzales et al., 2002), že ak vezmeme do úvahy vzájomný pomer celkovej hmotnosti a svietivosti jednotlivých druhov galaxií (ktorý "signalizuje“ ako intenzívne v nich prebiehala hviezdotvorba), tak zistíme, že v tzv. eliptických galaxiách bola spočiatku vel'mi intenzívna a skoro všetok počiatočný plyn bol spotrebovaný na vytvorenie niekol'kých generácií hviezd, ktoré sa príliš nelíšia svojou hmotnost'ou, svietivost'ou, vekom či chemickým zložením, pretože vel'a hviezd v týchto galaxiách je starých, málo hmotných a slabo svietiacich ( $\mathrm{v}$ dôsledku čoho je rozdiel medzi celkovou hmotnost'ou a svietivost'ou v týchto galaxiách vel'mi vel'ký), a pritom sa pohybujú okolo galaktického centra (Gonzales et al., 2002, s. 6) „ako muchy okolo žiarovky, po excentrických, často sa meniacich dráhach, čo priam vylučuje dlhé periódy stabilných podmienok", ktoré sú podl'a všetkého nevyhnutné pre vznik rovnako dlhodobo stabilnej a zároveň aj dynamicky sa vyvíjajúcej planetárnej sústavy.

V nepravidelných galaxiách typu IrI (v ktorých je síce látka rozdelená symetricky tak ako v špirálových galaxiách, ale nevyvinuli sa v nich špirálne ramená) a IrII (ktoré nadobudli svoj pokrivený tvar v dôsledku vzájomného pôsobenia so susednými galaxiami; Tayler, 1981, s. 73-74) sa zas hviezdotvorba rozbehla len

\footnotetext{
${ }^{4}$ V prospech čoho svedčia vel'mi závažné filozofické dôvody (či argumenty), podl'a ktorých sa nedá očakávat' (Urmancev, 1988, s. 121), že z jednej FPH okamžite vznikne iná, kvalitatívne vyššia, resp. z mnohobunkových organizmov hned' po ich vzniku kultúrou disponujúca l'udská spoločnost' (či komunikabilná civilizácia), ani nehovoriac o absurdných predstavách, že by sa mohol realizovat' okamžitý skok z fyzikálnej do sociálnej FPH a i.
} 
relatívne nedávno, a tak $\mathrm{v}$ nich očividne nemohlo dôjst' k žiadnemu postupnému a systematickému hromadeniu t'ažších chemických prvkov, (vrátane biogénnych, ako sú kyslík, dusík, uhlík, fosfor a síra); zatial čo pri šošovkovitých galaxiách sa dnes všeobecne predpokladá, že vel'mi málo medzihviezdneho plynu je v nich preto, lebo bol vymetený pri ich interakciách alebo kolíziách s druhými galaxiami, čo v nich muselo vyústit' do nižšieho množstva t'ažších chemických prvkov a tak pravdepodobne aj ovel'a nižšieho počtu biogénnych či obývatelných planetárnych sústav. Všetko tak nasvedčuje tomu, že takéto planetárne sústavy sa vo väčšom počte utvárajú len v špirálových galaxiách, o ktorých presnom počte $\mathrm{v}$ súčasnom vesmíre sa nad'alej vedú spory, ale nám postačí, ked' sa uspokojíme súdajom o ich 20percentnom výskyte (Gonzales et al., 2002, s. 5-6), čo by pri celkovom počte asi 100 miliárd galaxií v našom vesmíre viedlo $\mathrm{k}$ vel'mi zaujímavým číslam. ${ }^{5}$

Aj v tomto prípade je ale každá radost' predčasná, pretože biogénne (alebo obývatel'né) planetárne sústavy sa podl'a všetkého vyskytujú len pri niektorých dostatočne dlho a jasne svietiacich, ako aj masívnych hviezdach. Dlhodobé pretrvávanie takýchto sústav je teda určite vylúčené pri mimoriadne masívnych a vel'mi krátko svietiacich hviezdach spektrálnych tried $\mathrm{O}$ a B (ktoré vyžarujú svetlo a teplo len niekol'ko desiatok miliónov rokov), ako aj pri tzv. premenných hviezdach; vel'mi otázne na planétach, ktoré možno vznikli vo viacnásobných hviezdnych sústavách (v ktorých si sotva budú môct' dlhodobo udržat' stabilné obežné dráhy), pri mnohých hviezdach spektrálnej triedy F, ktoré vyžarujú aj v nebezpečnom ultrafialovom pásme; menej otázne pri malých a vel'mi dlho (až niekol'ko desiatok miliard rokov) žiariacich hviezdach spektrálnych tried $\mathrm{K}$ a M, kde je však problém s nízkým výkonom týchto hviezd, pretože tzv. okolohviezdne obývatel'né zóny okolo nich (v ktorých je dostatočne teplo na to, aby v nich mohla existovat' tekutá voda a spolu s ňou aj život) sa musia nachádzat' blízko materskej hviezdy a byt' tak ohrozované tzv. viazanou rotáciou, v dôsledku ktorej môžu byt’ tamojšie planéty na privrátenej strane prehrievané a na odvrátenej zbavené hviezdneho svitu. ${ }^{6}$

\footnotetext{
${ }^{5}$ Ked'že každá z týchto 20 miliárd galaxií, ak si pravdaže odmyslíme spomínané a vel'mi dôležité evolučné vplyvy, pozostáva z asi 100-200 miliárd hviezd ako potenciálnych sídiel tzv. inteligentného či rozumného života. ${ }^{6}$ Už pri relatívne nízkej pravdepodobnosti spontánneho vzniku vesmírnej civilizácie $\mathrm{v}$ takejto okolohviezdnej obývatel'nej alebo ,zelenej“ zóne (d’alej OOZ) by totiž mohol ich celkový počet v Galaxii výrazne stúpnut', pretože, ako dokazuje nedávny výskum W. Bonfilsa et al. (2011), pri 42 percentách tzv. červených trpaslíkov spektrálnej triedy M v našej galaxii by sa mali nachádzat' obývatel'né, resp. Zemi podobné planéty, pričom takýchto relatívne drobných, ale extrémne dlho žiariacich hviezd je v našej galaxii zo všetkých najviac, t. j. niekol'ko desiatok miliárd, a čo je ešte podstatnejšie, ako pre zmenu uvádzajú R. Barnes et al. (2012 s. 1, 19-21), ak budeme chápat' dlhodobú obývatel'nost' planéty ako funkciu hviezdy, planéty a planetárneho systému, tak budeme síce na jednej strane nútení uznat', že všetky planéty v OOZ hviezd s hmotnost'ou nižšou ako je $0,3 M_{S}$ budú aj pri slabo excentrickej obežnej dráhe bez ohl'adu na svietivost' hviezdy kvôli silnému slapovému efektu a akcelerovanému skleníkovému efektu (vedúcemu k úniku všetkej vody) neobývatel'né, zatial' čo planéty nachádzajúce sa v takejto zóne, ako je napríklad Gliese 667C c s hmotnost'ou 4,5 Zeme pri červenom trpaslíkovi o hmotnosti $0,3 M_{S}$, a to vo vzdialenosti $0,12 \mathrm{AU}$, si zrejme vd'aka orbitálnej stabilite ich planetárneho systému udržia svoje vodné zásoby a budú teda s najväčšou pravdepodobnost'ou aj dlhodobo obývatel’né (či biogénne).
} 
Najpravdepodobnejší sa teda zdá byt' spontánny vznik vesmírnych civilizácii pri Slnku podobných hviezdach, ibaže tých je v našej galaxii ovel'a menej ako červených trpaslíkov spektrálnych tried K a M (ako uvádzajú Ward s Brownleem (2003a, s. 258) len 2 až 5 zo 100), a čo je ešte horšie, všetko nasvedčuje tomu, že obývatel'né planéty sa podl'a všetkého môžu utvorit' a dlhodobo pretrvávat' len v tzv. galaktickom korotačnom pásme, prvý raz detailne opísanom Maročnikom a Muchinom už začiatkom 80. rokov minulého storočia, ako zvláštnej oblasti v Galaxii (1986, s. 154160) nachádzajúcej sa asi 10000 parsekov (kedy 1 parsek = 3,26 svetelného roka) od stredu Galaxie a tvoriacej tórus o hrúbke asi 815 svetelných rokov, pričom naša planetárna sústava sa momentálne nachádza v relatívne prázdnej oblasti medzi ramenami Strelca (kde zhruba pred 4,6 miliardami rokov vznikla) a Perzea (kam doputuje po uplynutí asi 3,2 miliardy rokov), kde je chránená nielen pred explodujúcimi supernovami, ktoré najčastejšie vybuchujú v špirálnych ramenách a v centrálnych oblastiach Galaxie, ale aj pred náhlou deštrukciou zapríčinenou gravitačným „kopancom“ od okolo prechádzajúcej hviezdy alebo viacnásobného (čiže z niekol'kých hviezd zloženého) hviezdneho systému.

Ako d'alej pokračujú Maročnik s Muchinom (tamže, s. 159-160), ak budeme počítat' s tým, že v danom pásme sa nachádza asi 70 miliónov Slnku podobných hviezd a zohl'adníme aj čas potrebný na prebehnutie biologickej evolúcie (a spontánny vznik vesmírnej civilizácie), tak budeme môct' počítat' s existenciou asi 40 miliónov VC v celej Galaxii, pričom tieto VC sa budú nachádzat' v dvoch protil'ahlých oblastiach korotačného pásma v relatívne nevel'kých vzdialenostiach jedna od druhej, čo sú určite pozoruhodné zistenia, a tak neprekvapuje, že tento koncept oživili začiatkom nášho tisícročia Gonzales et al. (2002), ktorý v tejto súvislosti podobne ako Maročnik s Muchinom hovorili o „zelenom páse“ života v Galaxii, zatial' čo my v snahe udržat” celistvost' nášho terminologického inventára hovoríme v tomto prípade radšej o galaktickej obývatel'nej zóne (GOZ), zdôrazňujúc, že ovel'a dôležitejšie ako tieto pojmové či terminologické upresnenia je zistenie Gonzalesa et al. (tamže, s. 3), že hranice GOZ sú určené aj „hmotou, ktorej vlastnosti umožňujú vznik obývatel'ných planét", pričom t'ažších chemických prvkov nesmie byt' (a väčšinou zrejme ani nie je) vGOZ privel'a, ako to fakticky vyplýva z niekol'ko miliárd rokov trvajúcej hviezdotvorby (a chemickej evolúcie) v Galaxii.

Bez dostatočného množstva t’ažších chemických prvkov by teda potenciálna terestrická planéta zostala príliš malá a nedokázala by si udržat' atmosféru ani geologickú aktivitu (resp. platňovú tektoniku), ba nevznikli by ani obrie joviálne planéty (tamže, s. 4), „pretože aj ony sa formujú okolo kamenných (či kovových ${ }^{7}$ ) jadier, ktoré síce nie sú vel'ké, ale majú potrebnú hmotnost'“; zatial' čo ak je kovových prvkov v materskom prachoplynovom mračne privel'a, možno očakávat', že z neho ${ }^{7}$ Čo je terminus technicus, pretože ako kovové označujú astronómovia všetky chemické prvky, ktoré sú t’ažšie
ako tie, čo vznikli tesne po vel'kom tresku, t. j. tie, ktoré vznikli v jadrách hviezd alebo počas explózie supernov. 
vzniknú privel'ké terestrické planéty s príliš vel'kým globálnym oceánom, ktorý zabráni podobne efektívnej kontrole teploty atmosféry, aká je najmä vd’aka platňovej tektonike možná na Zemi, a čo je zo všetkého najhoršie - pri takejto príliš vysokej metalicite a hustote protoplanetárneho disku obrie planéty bud' migrujú k materskej hviezde, alebo sa od nej postupne vzd'alujú, v dôsledku čoho sú jednotlivé terestrické planéty bud' povyhadzované zo svojej planetárnej sústavy, alebo zahnané do jej hviezdneho pažeráka, či zbavené ochrany joviálnych planét ako vel'mi efektívnych pohlcovačov tak asteroidálneho, ako aj kometárneho "smetia“, na základe čoho možno konštatovat', že pásmo komplexného života v našej galaxii (ako ho zachytili Lineweaver et al. (2004) v schéme č. 1) je naozaj úzke.

Od celkových trendov, ale aj detailov chemického vývoja v špirálových galaxiách by tak mohla silne závisiet' aj distribúcia obývatel'ných lokalít v nej, ako je zrejmé aj z d'alšieho zistenia Gonzalesa et al. (2002, s. 4), podl'a ktorých je vznik obývatelných planét vel'mi silne závislý od frekvencie výbuchov supernov typu I a II v Galaxii, ked’že pri explóziách supernov typu I, t. j. bielych trpaslíkov, vzniká najmä železo, nikel a kobalt, zatial' čo pri explóziách supernov typu II, t. j. vel'mi masívnych hviezd, sa syntetizuje kyslík, kremík, horč́́k, vápnik, titan a najmä thórium a urán; lenže hviezdotvorba $v$ našej galaxii $v$ dôsledku čoraz väčsieho množstva medzihviezdneho plynu „uväzneného“ v už žiariacich alebo vyhasnutých hviezdach pozvolna ustáva a čoraz zriedkavejšími sa stávajú explózie supernov typu II, čo zapríčiňuje, že nové Slnku podobné hviezdy sú omnoho „bohatšie na železo ako ich predchodkyne, ktoré sa sformovali pred 5 miliardami rokov“" z čoho vyplýva, že ich terestrické planéty budú síce mat' ovel'a „väčšie železné jadrá ako má Zem“, ale s ovel'a menším zastúpením thória a uránu, v dôsledku čoho budú zhruba „o 4,5 miliardy rokov generovat' o 40 percent menej tepla“ $\mathrm{z}$ ich rádioaktívneho rozpadu, ktoré generuje platňovú tektoniku a stabilizuje tak aj zemskú klímu. ${ }^{8}$

\footnotetext{
${ }^{8}$ Prostredníctvom uhlíkového, dusíkového a d’alších cyklov, ako detailne objasňujú Ward s Brownleem (2003b).
} 


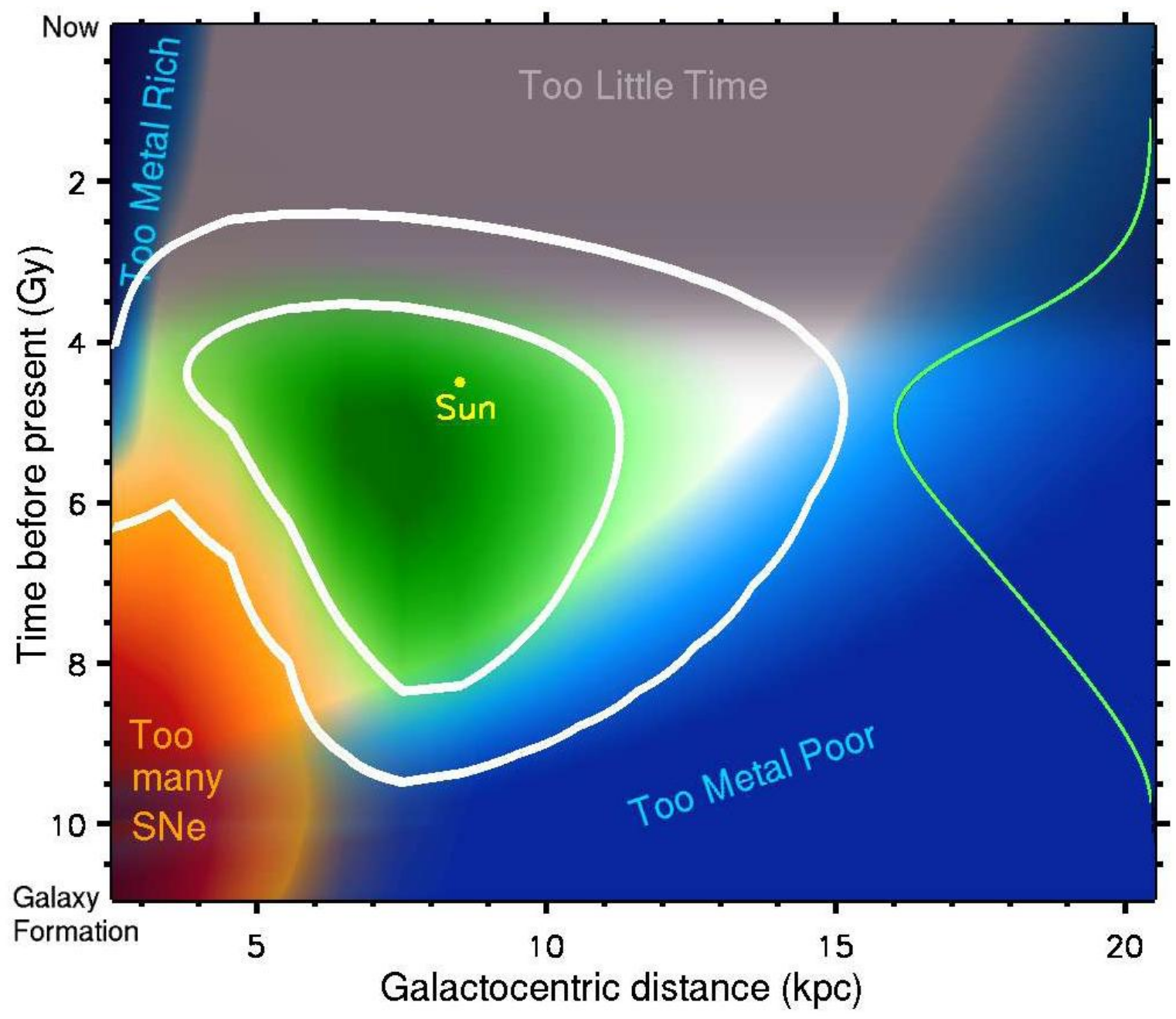

Schéma č. 1: Zobrazuje GOZ v disku našej galaxie na základe (Lineweaver et al., 2004, s. 5) intenzity hviezdotvorby, výskytu t’ažších chemických prvkov alebo metalicity (modrá farba), času potrebného na geologickú a biologickú evolúciu (zelená farba), dostatočnej vzdialenosti od explodujúcich supernov (červená farba), pričom jedna biela čiara ohraničuje 68 percent oblasti, v ktorej vznikajú hviezdy s obývatel'nými planétami, a druhá 95 percent tejto oblasti.

$\mathrm{Aj}$ z toho je zrejmé, že VC budú s rozdielnou pravdepodobnost'ou, t. j. v závislosti od aktuálnych počiatočných podmienok $\mathrm{v}$ danom planetárnom systéme a následnej evolúcie jeho prachoplynového materiálu, vznikat' len v niektorých biogénnych planetárnych sústavách, na základe čoho došlo podobne ako pri dosadzovaní číselných hodnôt do jednotlivých „položiek“ Drakeovej rovnice opät’ k vyčleneniu dvoch skupín bádatel'ov, kedy jedna skupina v typicky antropocentrickom duchu ${ }^{9}$

9 Extrémne kontroverznú problematiku antropocentrizmu, biocentrizmu a teocentrizmu diskutujeme v našej
dizertačnej práci s názvom Antropocentrizmus a antropický princíp (2012b, s. 33), kde v prvom rade rozlišujeme
medzi tromi druhmi tzv. globálno-evolučného antropocentrizmu ako špecifického životného a svetonázorového
postoja k okolitému svetu, a to (1) genetickým globálno-evolučným antropocentrizmom (GGA), podl'a ktorého
musel na počiatku nášho vesmíru existovat' bud' nejaký všemohúci Tvorca, ktorý ,zadával“ nášmu svetu jeho
parametre, alebo bližšie nedefinovaný prvotný hýbatel' (ktorý uviedol náš svet do chodu a ten takto dobre
„naštartovaný“ už len smeruje k nám neznámemu ciel'u), či vysoko špecifický stav vesmírnej matérie, z ktorého 
tvrdila (a tvrdí), že Slnečná sústava ako výsledok čisto náhodnej (kontingentnej alebo stochastickej) evolúcie pôvodného protoplanetárneho disku je jedinečná, a tak sotva môžeme očakávat', že sa okrem nej v Galaxii nachádzajú d’alšie sústavy tohto typu a spolu s nimi aj d'alšie komunikabilné $V C$, zatial' čo druhá skupina chápe parametre našej slnečnej sústavy ako súhrný výsledok tak počiatočných podmienok príznačných pre tento typ hviezdno-planetárnych sústav, ako aj deterministickostochastického vývoja, v rámci ktorého sa takéto biogénne a súčasne aj dlhodobo obývatel'né sústavy na základe čoraz viac alebo individuálnejšie modifikovaných pohybových zákonov hviezdno-planetárnej FPH (Zubkov, 1981, s. 136-141) v určitej fáze fyzikálno-chemického vývoja našej galaxie spoločne utvárajú.

Podl'a Warda a Brownleeho (2003a, s. 257-275), ako asi najznámejších reprezentantov prvej skupiny bádatel'ov, je teda naša planetárna sústava výnimočná nielen preto, že je zjavne výsledkom stochastického alebo jedinečného vývojového procesu, ale aj preto, že jej zložky sa vanalogickej konfigurácii s vel’kou pravdepodobnost'ou nemôžu znovu vyskytnút' v inej hoiezdno-planetárnej sústave, ako to vyplýva napríklad z existencie joviálnych planét nie v blízkosti materskej hviezdy (ako sme to doteraz väčšinou pozorovali $\mathrm{v}$ iných extrasolárnych planetárnych sústavách), ale na takmer kruhových orbitách d'aleko od centra Slnečnej sústavy (kde joviálne planéty chránia jej vnútorné oblasti pred vyššie spomínaným asteroidálnym či kometárnym „smetím“), ako aj z existencie relatívne vel'kého Mesiaca, ktorý podl'a Warda a Brownleeho (tamže, s. 231, 266) vznikol počas náhodnej kolízie Protozeme s protoplanétou niekol'kokrát väčšou ako Mars (vd'aka čomu sa môžeme tešit' z jeho stabilizujúceho vplyvu na sklon zemskej osi a stabilnej klímy), či vzájomného pomeru plôch a rozloženia kontinentov a oceánov, ktoré podporuje platňovú tektoniku a tým pádom aj stabilnú klímu, alebo relatívne nízkej frekvencie (a väčšinou aj intenzity) masových vymieraní počas biologickej evolúcie.

Už v roku 2007 však niektorí bádatelia (Pokorný, 2007, s. 26-27) upozorňovali, že pozorovaný prednostný výskyt joviálnych planét $\mathrm{v}$ tesnej blízkosti ich materskej hviezdy, resp. na silne excentrických obežných dráhach je jednoducho dôsledkom silného výberového efektu, kedy pri použitej pozorovacej technike a spektroskopickej metóde pozorujeme planéty práve tohto druhu, čo sa potvrdilo po úspešnom vypustení satelitu Kepler (umožňujúceho využit' ovel'a spol'ahlivejšiu zákrytovú metódu), pomocou ktorého boli objavené terestrické planéty len niekol'kokrát hmotnejšie ako naša Zem (Howard et al., 2011 a i.). S. Elser at al. (2011, s. 1, 10) zas na

(bez ohl'adu na množstvo kvalitatívnych medzistupňov či FPH) človek chápaný ako čisto biologický subjekt (čiže tzv. inteligentný život) musí, tak ako v rámci silného a finálneho antropického princípu (SAP a FAP; Barrow-Tipler, 1986, s. 21, 23), napokon vzniknút'; (2) procesuálnym globálno-evolučným antropocentrizmom (PGA), pri ktorom sa predpokladá, že biologická evolúcia s človekom ako svojím posledným článkom je vysoko nepravdepodobným procesom (a človek je tak vo vesmíre výnimočným, zrejme len na Zemi sa vyskytujúcim fenoménom), a (3) finalistickým globálno-evolučným antropocentrizmom (FGA), v rámci ktorého je človek považovaný za konečný ciel' multivesmírneho procesu, ako je tomu aj v prípadoch, kedy je tento ciel’ ,posunutý“ do akéhosi bodu Omega, v ktorom má človek nakoniec splynút's Bohom (Teilhard de Chardin, 1990, s. 215-226). 
základe počítačového modelovania vývoja solárneho protoplanetárneho disku zistili, že podobné zrážky väčších protoplanét, aké viedli k vzniku „dvojsystému“ Zem- Mesiac, nie sú pravdepodobne vôbec výnimočné (ako sa nás snažia presvedčit' nielen Ward a Brownlee, ale aj všetci antropocentricky orientovaní zástancovia hypotézy o výnimočnosti Slnečnej sústavy), ale pomerne časté, pretože 1 z 12 terestrických planét v OOZ by podl'a nich mala disponovat' dostatočne vel'kým mesiacom (schopným dlhodobo stabilizovat' zemskú os), s možnými odchýlkami na úrovni $1: 45$ či $1: 4$, čo je v oboch prípadoch vel'mi nádejné číslo.

Ešte d'alej zašiel vo svojej dizertačnej práci D. Williams (1998), ktorý využívajúc celú škálu výskumných metód (vrátane modelovania klímy, sympletického integrovania a pod.) akoby postavil celú túto diskusiu „z hlavy na nohy“ a dospel k celému radu pozoruhodných zistení, konštatujúc napríklad (tamže, s. 5 a n.), že problém s viazanou (alebo synchrónnou) rotáciou pri terestrických planétach v OOZ hviezd spektrálnej triedy $M$ môže byt' riešený jednoducho na základe hypotézy o prenose tepla z privrátenej strany planéty na odvrátenú prostredníctvom atmosférického prúdenia (či vetra), alebo "sofistifikovanejšie“ (ako je tomu pri Merkúre) asynchrónnou spin-orbitálnou rezonanciou, ul'ahčujúcou vyrovnávanie vel'kých teplotných rozdielov a zadržiavanie chemicky stálej atmosféry s $\mathrm{CO}_{2}$ a $\mathrm{H}_{2} \mathrm{O}$ v dostatočnom množstve na takýchto potenciálne obývatel'ných terestrických planétach. Williams zároveň počíta aj s existenciou Zemi podobných a dlhodobo obývatel'ných planét na okraji OOZ, ktoré však (tamže, s. 43 a n.) budú musiet' mat' v atmosfére viac $\mathrm{CO}_{2}$, resp. inak naklonenú rotačnú os, výhodnejšie rozmiestnené kontinenty a pod., aby sa primerane mohlo zväčšit' či zmenšit' aj zvetrávanie a tým pádom aj stabilizačný účinok uhlíkového, dusíkového a d'alších cyklov.

Podl'a Williamsa (tamže, s. 46-47) ak umiestnime (modelovú) Zem do vzdialenosti 1,4 AU od Slnku podobnej hviezdy a nakloníme jej rotačnú os do 90 uhla, pričom všetky ostatné parametre ponecháme nezmenené, s prekvapením zistíme, že spolu so vzrastom celkového množstva $\mathrm{CO}_{2}$ v atmosfére sa zvýši aj jej globálna tepelná inercia, v dôsledku čoho budú jednotlivé klimatické zóny ovel'a pomalšie reagovat' na zmeny $\mathrm{v}$ insolácii a extrémne sezónne teplotné odchýlky budú výrazne redukované. A čo je ešte prekvapujúcejšie, takto umiestnená a naklonená Zem bude podl'a všetkého zbavená l'adu a schopná udržat' život na ovel'a väčšej ploche ako tá, ktorú práve obývame (hoci sa fakticky bude nachádzat' za hranicami OOZ, ktorá sa podl'a väčšiny bádatel'ov rozkladá vo vzdialenosti zhruba 0,9 až 1,1 AU). Rovnako šokujúce sú aj d’alšie výsledky Williamsovho štúdia modelových terestrických planetárnych sústav. Ako tvrdí (tamže, s. 99 a n.), ak by bol napríklad Mesiac len o polovicu menší (presne $\leq 0,47 M_{M e}$ ), už dnes by bol precesný pohyb zemskej rotačnej osi chaotický, čo ale podl'a neho platí len vo vzdialenosti 0,9 až $1,4 \mathrm{AU}$, zatial' čo vo vzdialenosti 0,9 AU od Slnka by aj pri neprítomnosti Mesiaca mal byt' rotačný a precesný pohyb Zeme opät' stabilizovaný. 
K stabilizácii rotačno-precesného pohybu našej (a ktorejkol'vek rovnako vel'kej alebo hmotnej terestrickej) planéty však musí dôjst' aj vtedy (tamže, s. 101), ked' bude obiehat' Slnko po súčasnej obežnej dráhe, nebude mat’ pri sebe žiadny dostatočne hmotný mesiac, ale bude sa môct' silnejšie "naviazat" na Jupiter posunutý do vzdialenosti 2,0 AU od Slnka, čo len znova potvrdzuje (tamže, s. 107), aký citlivý je sklon planetárnej rotačnej osi na zmeny v jej orbitálnej pozícii; aj ked', ako férovo konštatuje Williams na 101. strane, zatial' sa nedá jednoznačne stanovit', či budú obežné dráhy Zeme a Marsu dlhodobo stabilné počas miliárd rokov s Jupiterom nachádzajúcim sa vo vyššie uvedenej vzdialenosti (alebo celou planetárnou sústavou posunutou takto ovel'a bližšie k nejakej inej Slnku podobnej hviezde). Nakoniec, obývatel'né by podl'a Williamsa mohli byt' (tamže, s. 111) aj mesiace obiehajúce menšie joviálne planéty v OOZ v tom prípade, ak budú hmotnejšie ako 0,23 Mz, pretože len stakouto hmotnost'ou sa môžu rozohriat' natol'ko, aby mohli disponovat' platňovou tektonikou, udržat' si dostatočne hustú atmosféru i magnetické pole, aj ked' pri rezonančnej gravitačnej interakcii so susednými mesiacmi sa pripúšt'a aj ich nižšia hmotnost' v rozsahu od 0,12 do $0,23 \mathrm{MZ}{ }^{10}$

Napriek tomuto všetkému sa však predsa len zdá najpravdepodobnejšie, že vesmírne civilizácie spontánne vznikajú najčastejšie na terestrických planétach v OOZ, ako vyplýva aj zo Zinneckerovej štúdie z roku 2003, podl’a ktorej (tamže, s. 2 a n.) terestrické planéty zrejme vznikajú len okolo (Slnku vel'mi podobných) hviezd, ktorých metalicita dosahuje aspoň $1 / 2$ slnečnej metalicity. Ak sa teda novovznikajúca planetárna sústava vyznačuje o niečo nižšou metalicitou, v jej centrálnych oblastiach budú vznikat' len vel'mi malé kamenné planéty alebo asteroidy, na ktorých sa však biologická evolúcia nemôže vôbec rozvinút, pretože si nedokážu vytvorit' a udržat' primerane hustú, priezračnú a tepelne priestupnú atmosféru, nebudú mat' dostatočne vel'ké kovové jadro, generujúce ochranné magnetické pole, a nebudú si môct' ani dlhodobo udržat' svoje počiatočné vnútorné teplo, pretože ich príliš malé a slabo rozohriate planetárne jadro vychladne ešte predtým, ako sa nad ním bude môct' rozbehnút' životodarná vulkanická činnost', platňová tektonika a uhlíkový cyklus. Terestrické planetárne sústavy by teda zrejme nemali vznikat' v hale našej galaxie či Vel'kom a Malom Magellanovom mraku, pretože všade tam je pozorovaná metalicita nižšia ako požadovaných $1 / 2$ slnečnej metalicity. ${ }^{11}$

Otvorenou však nad'alej zostáva otázka, s akou frekvenciou a v akom dlhom časovom úseku (alebo intervale) vesmírne civilizácie vo vyššie vymedzených

\footnotetext{
${ }^{10}$ Ked’že v takýchto prípadoch je potenciálne obývatel'ný mesiac dodatočne zohrievaný slapovými silami.

${ }^{11}$ Aj ked' opät' len pod čiarou musíme poznamenat', že Zinnecker vôbec nevylučuje (tamže, s. 3), že okolo niektorých starších hviezd 2. populácie sa už dávnejšie utvorili menšie protoplanetárne disky s nižším obsahom kovových prvkov a aj s nižším diskovým uhlovým momentom, v ktorých je „nižší pomer hmotnosti prachu k hmotnosti plynu kompenzovaný distribúciou prachovej hmotnostnej zložky cez menší disk“, čo napomáha udržaniu rovnako vel'kej povrchovej hustoty prachu, aká je predpokladaná pri vzniku našej planetárnej sústavy.
} 
lokalitách vznikajú, resp. môžu byt' spontánne distribuované, po zodpovedaní ktorej možno určit' hustotu ich výskytu a tak aj reálne možnosti ich vzájomnej komunikácie a/lebo interakcie. Ako prvý sa ju pokúsil zodpovedat' V. Troickij vo vel'mi odvážnom článku z roku 1981, podl'a ktorého (v úplnom súlade s Webbovým riešením Fermiho paradoxu č. 10 (Webb, 2002, s. 72-74), kedy VC nepozorujeme preto, lebo k nám ešte nestihli doletiet') vznikajú všetky VC v našom vesmíre zhruba $v$ tom istom čase, pretože aj živé systémy vznikajú vo vesmíre iba raz v relatívne krátkom časovom úseku (t. j. akoby explozívne) v zjavnej závislosti od vyššie diskutovaného fyzikálno-chemického vývoja našej galaxie (a očividne aj preto, ako vyplýva z predošlého, že všetky VC vznikajú po uplynutí zhruba rovnako dlhej a rovnako usmerňovanej biologickej evolúcie). Existencia ovel’a starších a pravdepodobne aj vyspelejších supercivilizácií tak pri nevyhnutnom rýchlostnom "rozptyle“ biologického a sociálneho vývoja jednotlivých VC nie je vylúčená, ale za daných okolností natol'ko nepravdepodobná, že s ňou nemusíme počítat'.

Z hl'adiska samotnej distribúcie VC v našej galaxii (a nakoniec aj v celom vesmíre) je však ešte dôležitejšie Troického tvrdenie (tamže, s. 1125-1126), že pri jeho prístupe je možné konečne zaviest' do odhadovania výskytu VC v našom vesmíre štatistický zákon či štatistický výskum ako taký, pretože na rozdiel od jednoduchého dosadzovania číselných hodnôt do Drakeovej rovnice (pri ktorom sa implicitne predpokladá, že VC vznikajú vo vesmíre fakticky nepretržite a kontinuálne v tých najrozmanitejších lokalitách alebo epochách) možno pri ňom zaviest' obmedzenia alebo limitujúce faktory, ktoré súvisia s konkrétnou determináciou ich výskytu a počtu na základe predošlej fyzikálno-chemickej evolúcie vGalaxii, a následne aj obmedzenia, ktoré vyplývajú z vyššie spomenutej rozdielnej rýchlosti biologickej evolúcie na jednotlivých biogénnych planétach, na základe čoho potom predkladá celý súbor takto modifikovaných už nie Drakeových, ale Troického rovníc, ako napríklad rovnicu (tamže, $\quad$ s. 1125) zachytávajúcu zákon distribúcie časových úsekov, ktoré sú potrebné pre zavŕšenie tej-ktorej biologickej evolúcie v našej galaxii $^{12}$, či rovnicu zachytávajúcu aktuálnu distribúciu VC v Galaxii za predpokladu, že VC v nej naozaj po určitom čase vymierajú alebo zanikajú ${ }^{13}$.

Bohužial', okrem tvrdenia, že takýto jednorázový vznik života v celom vesmíre (a teda aj v Galaxii) v mimoriadne krátkom časovom intervale je v súlade

${ }^{12}$ Podla ktorej $p\left(\tau_{l}\right)=\left(\alpha \bar{\tau}_{l} \sqrt{2 \pi}\right)^{-1} \exp \left[-\frac{1}{2}\left(\frac{\tau_{l}-\bar{\tau}_{l}}{\alpha \bar{\tau}_{l}}\right)^{2}\right]$, kedy $\tau_{l}$ predstavuje dobu trvania biologickej evolúcie na tej-ktorej biogénnej planéte, $\bar{\tau}_{l}$ gaussovský zákon distribúcie biologickej evolúcie okolo určitej strednej hodnoty a $\pm \alpha \bar{\tau}$ štandardnú odchýlku $\tau_{l}$ od danej strednej hodnoty s tým, že $\alpha<1$.

${ }^{13}$ Podla ktorej $N_{c L}(t)=R f_{p} n_{l} \tau_{p} f_{l} f_{c}\left\{\varphi\left(t-\bar{t}_{c}\right)-\varphi\left(t-L-\bar{t}_{c}\right)\right\}$; kde $\varphi\left(t-t_{c}\right)$ predstavuje bezrozmernú funkciu, ktorá zohl'adňuje rozdielne rýchlosti evolúcie na rôznych planétach, na ktorých VC vznikajú a neskôr podl'a danej rovnice už nielen na nich (tamže, s. 1127), ale v celom vesmíre asi po 7 miliardách rokov zanikajú. 
s predstavami o jednotnom vývine matérie vcelom vesmíre (a teda aj jeho nevyhnutnosti a zákonitosti), Troickij (tamže, s. 1122) neuviedol žiadne fakty ani presvedčivé dôkazy, ktoré by jeho koncepciu potvrdzovali, a tak muselo prejst' takmer 20 rokov, kým si astrobiológovia a astrosociológovia rovnako ako on uvedomili, že nielen fyzikálno-chemický (ako sme mohli vidiet' u Gonzalesa et al., 2002), ale aj biologický vývin matérie vGalaxii (a celom vesmíre) musí byt' globálne usmerňovaný či "kanalizovaný“. Najväčšmi k tomu prispela Annisova dnes už klasická štúdia z roku 1999, v ktorej bol Fermiho paradox vyriešený na základe hypotézy o permanentnom likvidovaní komplexného života v Galaxii počas tzv. zábleskov gama žiarenia (angl. gamma ray bursts - GRB) v intervale asi $10^{8}$ rokov (čo je podl'a Annisa (1999, s. 1) časový úsek potrebný na vznik inteligentného života), na základe čoho potom Annis uzavrel, že sa nachádzame práve na konci jedného takého cyklu a VC (rovnako ako $\mathrm{v}$ Troického texte) práve $v$ Galaxii v čoraz väčšom počte vznikajú. Annis pritom dokázal anticipovat' a dopredu vyriešit' aj d'alší problém.

Ako totiž zistili Lineweaver et al. (2004, s. 6) a ako vyplýva aj zo schémy č. 1, väčšina hviezd v GOZ, ktorá sa podl'a nich rozprestiera vo vzdialenosti 7 až 9 kiloparsekov od centra Galaxie, t. j. až 75 percent, je v priemere o 1 miliardu rokov starších ako Slnko, a tak naozaj vzniká otázka, ako je možné, že napriek tomu pri nich za tak dlhé časové obdobie nevznikli žiadne supercivilizácie, ktoré by o sebe bud' dali vediet' priamo, alebo aspoň nepriamo, počas svojich l'ahko identifikovatel'ných astroinžinierskych aktivít. J. Annis však dopredu vyvracia takéto protiargumenty, konštatujúc (1999, s. 2), že frekvencia GRB (pri ktorých sa počas 10- -sekundových zábleskov uvol'ňuje viac ako $10^{52}$ ergov) bola určite ovel'a vyššia v minulosti, kedy bola hviezdotvorba v Galaxii ovel'a intenzívnejšia (dosahujúc svojho maxima pred asi 10 miliardami rokov), a odvtedy sústavne a výrazne klesá, ako vyplýva aj z najviac uznávanej hypotézy o pôvode GRB, podl'a ktorej tieto záblesky vznikajú pri zrážkach neutrónových hviezd. Tento argument vyzdvihuje aj M. Ćirković (2009, s. 23), ktorý zároveň chápe GRB ako určitý mechanizmus, pomocou ktorého sa doslova resetujú a znovu nastavujú galaktické biologické hodiny a vývinové fázy tak, aby VC predsa len vznikali zhruba v tom istom čase. ${ }^{14}$

\footnotetext{
${ }^{14}$ Podotýkajúc vo svojej d’alšej štúdii (Ćirković et al., 2009, s. 18), že obývatel'né Zemi podobné planéty môžu byt' zriedkavé v čase, ale sotva v priestore, pretože práve „teraz“ dospievajú ich biosféry v celej Galaxii vd'aka GRB-mechanizmu do štádia, kedy v nich vznikajú komunikabilné VC a následne aj supercivilizácie napríklad Kardašovovho typu č. III , ako to zachytáva schéma č. 2 prebratá z Ćirkovićovej vlastnej štúdie z roku 2009.
} 


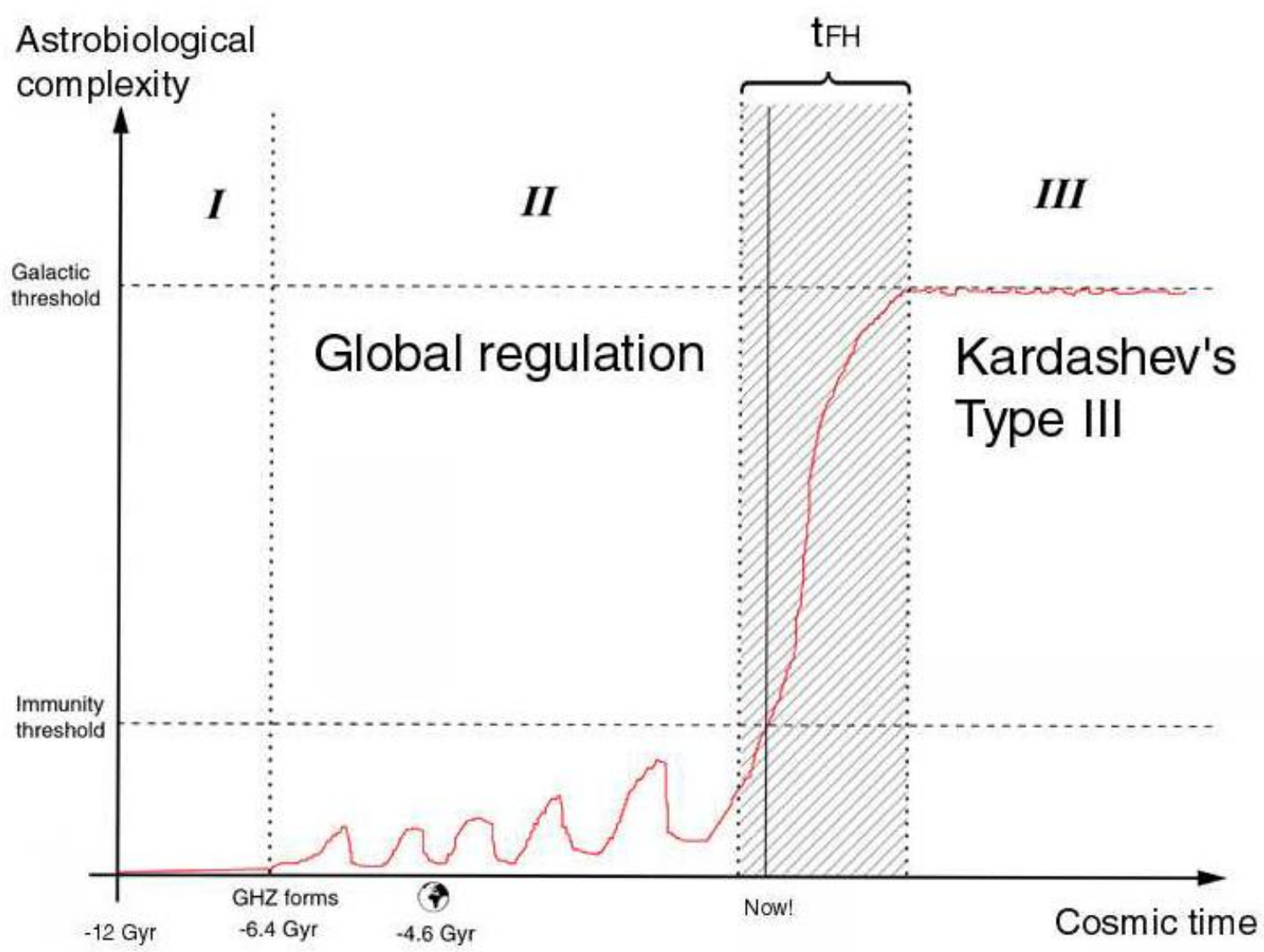

Schéma č. 2: Zobrazuje fungovanie GRB regulačného mechanizmu v rámci našej galaxie od jeho „nástupu“ pri vzniku GOZ pred 6,4 miliardami rokov až po ukončenie jeho fungovania pri vzniku komunikabilnej VC a jej rýchlom vývine až ku Kardaševovej supercivilizácii typu č. III vo Fermiho-Hartovom čase $t_{F H}$ (in Ćirković, 2009, s. 27), ktorá (Rubcov - Ursul, 1984, s. 36-37) spotrebúva energiu v galaktickom rozsahu tempom $4 \mathrm{x}$ $10^{44} \mathrm{erg} / \mathrm{s}$., zatial' čo solárna (alebo hviezdna) VC tempom $4 \times 10^{33} \mathrm{erg} / \mathrm{s}$. a súčasná pozemská VC tempom $4 \times 10^{19} \mathrm{erg} / \mathrm{s}$.

Stotožňujeme sa pritom aj s Ćirkovićovou kritikou Carterovho antropického argumentu (Ćirkovic et al., 2009), ale v žiadnom prípade nie so spôsobom či argumentáciou, akou bola realizovaná. Ak totiž plne akceptujeme kritické výhrady Ćirkovića et al. (tamže, s. 2) voči Carterovmu tvrdeniu, že inteligentný život (a/lebo život vôbec) vzniká vo vzt́ahu k okolitému astrofyzikálnemu prostrediu v náhodne „zvolenej“ epoche, t. j. akoby nekorelovane s jeho globálnym vývojom (Carter, 1983), ako aj ich plne odôvodnené tvrdenie, že tzv. inteligentný život vzniká s omnoho väčšou pravdepodobnost'ou v oblastiach, kde sú procesy, ktoré mu napomáhajú, vel'mi silne korelované či previazané, pričom jednoduchšie formy života (tamže, s. 8) ul'ahčujú či urýchl'ujú vznik jeho komplexnejších foriem ${ }^{15}$, sotva môžeme akceptovat'

\footnotetext{
15 Č́m sa jasne potvrdzuje predpokladovost' biologickej evolúcie, resp. jej silná determinovanost' a usmernenost' predošlými vývinovými štádiami, v dôsledku čoho, ako sme už viackrát upozorňovali (Burgan, 2012c, s. 7 a i.), inteligenciu nemožno chápat', tak ako to robí E. Mayr (in Davies, 2001, s. 283), ako niečo čo môže vzniknút' kedykol'vek počas pozemskej biologickej evolúcie, v ktorejkol'vek jej vývinovej fáze či rodovej alebo druhovej
} 
ich stotožnenie sa s Gouldovým spochybňovaním progresívnej línie v biologickej evolúcii, ktorá sa nielen podl'a nás (Burgan, 2012c), ale aj podl'a viacerých d'alších autorov (Stanko, 1989; Rosslenbroich, 2009) jasne manifestuje najmä rastúcou autonómnost'ou jednotlivých druhov organizmov. Okrem toho, za ovel'a závažnejšie považujeme Carterove svojvol'né tvrdenia o vysokej nepravdepodobnosti tzv. kritických krokov v biologickej evolúcii (Carter, 1983). ${ }^{16}$

Najproblematickejšie zo všetkého je ale Ćirkovićovo tvrdenie (2009, s. 8), že dnes nie je možné jednoznačne definovat' život ako taký ani inteligenciu ako takú, resp. vybrat' si zo všetkých najviac sa ponúkajúcich definícií týchto fenoménov takú, na ktorej by sa viac-menej zhodli všetci biológovia alebo kognitívni vedci, pretože, ako sme ukázali v našej poslednej publikovanej štúdii o usmernenosti biologickej evolúcie (Burgan, 2012c, s. 23 a n.), skutočne je možné jednoznačne definovat' život v konfrontácii s jemu podobnými fenoménmi bud' na základe jeho špecifických štruktúrnych prvkov (čiže jednotlivých buniek) a zákonov, ktoré riadia ich správanie, alebo na základe jeho kvalitatívnej a kvantitatívnej odlišnosti od d'alších $\mathrm{FPH}$, najmä geologickej, ktorá mu priamo predchádzala a z ktorej sa život zrodil, a sociálnej, ktorá ho v rámci antroposociogenézy kvalitatívne prekonala a priebežne tak ukončila jeho zvrchovanú „vládu“ nad zemskou ekosférou; zatial' čo inteligenciu ako takú podl'a nás vel'mi precízne vymedzili S. Legg a M. Hutter (2007a, s. 9), ktorí najprv uviedli niekol'ko desiatok definícií inteligencie a potom z nich vyextrahovali spoločný význam, tvrdiac, že inteligencia je jednoducho mierou "agentovej schopnosti dosahovat' ciele v širokom spektre prostredí".

Ešte horšie však je, že napriek tomuto definičnému „deficitu“ sa Ćirković vo svojej vlastnej štúdii z roku 2009, venovanej práve nami diskutovanému Fermiho paradoxu a jeho riešeniam, rozhodol bez hlbšieho zváženia pracovat' s jeho (a Bradburyho, 2005) definíciou „pokročilej technickej civilizácie“ ako (Ćirković, 2009, s. 8-10) „spoločenstva bytostí, ktoré sú schopné manipulovat’ shmotou a energiou v dostatočne vel’kom objeme či škále ${ }^{\text {"17 }}$, pričom dokážu nielen odolávat' vesmírnym impaktom alebo tzv. supersopkám, ale aj rozvinút' svoje priemyselné a výpočtové aktivity do takej miery, že sú pozorovatel'né na medzihviezdne vzdialenosti, čo znie

línii, ale až po vytvorení určitých nevyhnutných predpokladov, t. j. po vzniku čoraz komplexnejších, autonómnejších a teda aj vyvinutejších organizmov, ako je podl’a nás zrejmé z argumentácie Ćirkovića et al. a z vyššie spomínaného Mayrovho zmätočného tvrdenia, podla ktorého „na Zemi z miliónov rodových línií organizmov a vari z 50 miliárd prípadov vzniku nových druhov iba jedna cesta viedla k vysokej inteligencii“, na základe ktorého je Mayr presvedčený, že vznik inteligencie ako takej bol na Zemi vysoko nepravdepodobný, pretože rozumné bytosti jednoducho nemôžu vzniknút' náhlym saltacionistickým skokom napriklad z dážd'ovky.

${ }^{16}$ Kedy je vzhl'adom na celkovú možnú dížku biologickej evolúcie na Zemi apriórne vysoko nepravdepodobné, ako tvrdí Carter, že by sa v danom časovom intervale $\sim 10$ miliárd rokov realizovali aj na iných Zemi podobných planétach viac ako dva z viacerých na nej realizovaných vysoko nepravdepodobných evolučných krokov; aj ked' je zrejmé, že pravdepodobnostné výpočty realizované na základe jediného exemplára z potenciálne vysoko početnej a vari aj variabilnej exobiologickej a exosociologickej vzorky sú krajne nedôveryhodné a nespol'ahlivé. ${ }^{17}$ V origináli: „Similarly, we use the locution ,advanced technological civilization'... as denoting a community of intelligent beings capable of manipulating matter and energy on sufficiently large scale.“ Preklad R. B. 
síce presvedčivo, ale nijako hlbšie sa nevzt'ahuje k našej, pozemskej VC, ktorú už dávnejšie vel'mi precízne vymedzili Rubcov s Ursulom vo svojej pozoruhodnej knihe (1984, s. 59 a n.) a otvorili tak cestu ku skutočne vierohodnej a konzekventnej lokalizácii VC v našej galaxii, čo sa v druhej časti nášho príspevku práve na základe odlíšenia pozemskej VC a pozemskej sociálnej FPH od nadsociálnych FPH či tzv. pokročilých technických civilizácií pokúsime dokázat', vychádzajúc pritom aj z rozsiahlej literatúry o možných podobách umelej inteligencie, ako aj materiálno-energetických limitoch výpočtových procesov v našom vesmíre.

\section{Vesmírne civilizácie pretrvávajú vo vesmíre len niekol'ko sto až tisíc rokov}

V. Rubcov a A. Ursul začínajú podobne ako S. Legg s M. Hutterom rozsiahlym predstavením definícií vesmírnej civilizácie dostupných vo vtedajšej sovietskej astrosociologickej literatúre, zdôrazňujúc, že pri kybernetických definíciách VC, v ktorých je vyzdvihovaný ich výpočtový a funkcionálny rozmer, resp. homeostatické schopnosti, sa vel'mi často nezohl'adňuje sociálna podstata VC, ktoré však možno chápat' a vymedzovat' v úzkom a širokom slova zmysle, kedy v prvom prípade (Rubcov - Ursul, 1984, s. 69) definujeme VC ako súbor konajúcich sociálnych indivíduí, ktoré disponujú vedomím, zatial' čo v druhom už vymedzujeme VC ako „sociálny subjekt v širokom slova zmysle“, čiže sociokultúrny systém, ktorý (tamže, s. 65) nielen pozostáva z daných indivíduí, ale aj koná určitým úplne konkrétnym a/lebo historicky daným spôsobom, využívajúc pritom kultúru "ako komplex prostriedkov a mechanizmov zabezpečujúcich tento spôsob existencie“. Základné stavebné, štruktúrne alebo substanciálne prvky VC, t. j. jednotlivých l'udí, pritom nemožno chápat' mechanicky a redukcionisticky ako jej púhe zložky, pretože, ako podotýkajú Rubcov s Ursulom na 68. strane, sú v istom zmysle slova totožné so samotným spoločenstvom, ktoré sebou stelesňujú, vyjadrujú a manifestujú. ${ }^{18}$

Z metodologického a širšieho konceptuálneho hl'adiska je mimoriadne dôležité aj ich priebežné vymedzenie civilizácie (tamže, s. 68-69) ako určitého štádia vo vývoji spoločnosti a zároveň "skupinového sociálneho subjektu určitej úrovne, sociokultúrnej totožnosti, ktorý je ohraničený v priestore a čase", ako aj ich opakované poukazovanie na konkrétnost'́, a teda aj historickost' tohto sociálneho subjektu, pri ktorej na historickej rovine jeho analýzy (tamže, s. 73) treba dôkladne skúmat' najmä mechanizmus jeho genézy, hybné sily a všeobecný smer jeho vývoja a "tiež zvláštnosti tohto vývoja v jeho rôznych fázach“, no a nakoniec aj proces jeho zániku -

\footnotetext{
${ }^{18}$ Práve preto, vysvetl'ujú d’alej Rubcov s Ursulom (tamže, s. 68-69), že l'udia v sebe zahrňujú celý sociálny subjekt (alebo systém) v akejsi koncentrovanej podobe či forme, podstatne sa líšia napríklad od „,spoločenstiev“ včiel alebo mravcov, v ktorých je každý jedinec skutočne jedincom v pravom slova zmysle, t. j. púhym prvkom daného „spoločenstva“, jednoduchou čiastkou, ktorá je „zbavená celostnosti“ a fakticky aj vývojaschopnosti.
} 
"deštrukcie alebo zmeny v podstatne iný objekt (objekty)“. Práve na tomto základe totiž mohli Rubcov a Ursul (d'alej aj R\&U) ako jedni z mála definovat' VC úplne konkrétne a realisticky jednak ako planetárnu vesmírnu civilizáciu (PVC), totožnú (tamže, s. 72; podč. R\&U) s množinou "všetkých sociálnych organizmov v hraniciach danej planéty, zjednotených spoločnou genézou alebo geneticky odlišných, ale spojených jednou spoločnou sociokultúrnu štruktúrou" ${ }^{19}$, jednak spoločne s T. Berzinovou (tamže, s. 82) ako „zvláštny prejav sociálnej formy pohybu vo vesmíre“, disponujúci vedomím a priemyselnou výrobou.

Rubcov a Ursul tak posunuli diskusiu o VC a ich lokalizácii vo vesmíre na ovel'a vyššiu kvalitatívnu úroveň, pretože na základe nimi ponúkaných poznatkov už bolo možné začat' uvažovat' nielen nad možnou podobou štruktúrnych prvkov teoreticky možnej nadsociálnej FPH, jej špecifickými zákonmi a pod., ale aj nad dynamikou samotnej pozemskej vesmírnej civilizácie, ktorá síce dokáže načúvat' signálom z vesmíru v mnohých frekvenčných pásmach, ale zd'aleka nie je schopná dlhodobo a intenzívne vysielat' správy o svojej existencii a činnosti do potenciálne obývatel'ných lokalít našej galaxie jednak preto, že jej to neumožňuje jej stále nedostatočne výkonná ekonomika, jednak preto, ako upozorňoval už v roku $1986 \mathrm{~K}$. Rebane, že takéto vysielanie (najmä ak nie je nasmerované do "podozrivých" či obývatel'ných lokalít) je extrémne energeticky náročné, a to aj pre civilizáciu, ktorá dokáže pracovat' (a existovat') s ovel'a väčšími energetickými a dátovými tokmi ako naša, pretože je zároveň nútená riešit' čoraz zložitejší problém ochladzovania povrchu svojej planéty a celkovej civilizačnej (alebo sociálno-ekonomickej) nestability, ktorá je neodmyslitel'ná (tamže, s. 32) od termodynamicky nerovnovážnych disipatívnych štruktúr, medzi ktoré nevyhnutne patria všetky civilizácie. $^{20}$

Najmä tieto sociálno-ekonomické súvislosti by preto podl'a nás mali určovat' celkový ráz diskusie o možnej lokalizácii a distribúcii VC, pretože nielenže umožňujú jednoznačne definovat' typickú VC ako sociálno-ekonomický subjekt s jednotlivými "l'ud'mi“ ako svojimi štruktúrnymi prvkami, ktorí síce dokážu prijímat' rádiové signály alebo správy z vesmíru, nie však dlhodobo a intenzívne vysielat', ale aj ohraničujú celkovú dobu jej trvania na niekol'ko sto až tisíc rokov, po uplynutí ktorých dôjde k podstatnej kvalitatívne zmene štruktúrnych prvkov

\footnotetext{
${ }^{19}$ V prípade, že čast’ danej planéty je obývaná „prišelcami““ s iným biologickým základom, resp., čo je ešte extrémnejší variant, daná PVC pozostáva z dvoch alebo viacerých miestnych civilizácií (či sociálnych organizmov), ktoré však vznikli z rôznych biologických druhov, v odlišných podmienkach a v rozdielnom čase.

${ }^{20}$ Sám Rebane pritom d’alej počíta (tamže, s. 32-35) s existenciou tzv. mlčiacich civilizácií, ktoré napriek svojej vysokej ekonomickej výkonnosti usúdili, že je pre nich nevýhodné alebo druhoradé vynakladat' prostriedky na medzihviezdne vysielanie s vel'mi neistým výsledkom či informačným alebo kultúrnym ziskom (nehovoriac o etickom rozmere celej diskusie, kedy môže mat' informácia od vyspelejšej civilizácie na tú zaostalejšiu skôr deštruktívny ako konštruktívny účinok), ba aj s existenciou $t z v$. zhovorčivých civilizácií, ktoré dokázali preniest' mohutné vysielače mimo ekosféru svojej materskej planéty a skutočne sa snažia oboznámit’ svojich vesmírnych susedov so svojím tezaurom, aj ked' ich z vyššie uvedených dôvodov či príčin považuje za extrémne zriedkavé.
} 
sociálnej FPH a zásadnej zmene behaviorálneho režimu takejto zanikajúcej VC, resp. konkrétnej formy sociálnej FPH, ako je zrejmé najmä z dnes čoraz populárnejšieho a čoraz viac diskutovaného konceptu technickej alebo technologickej singularity (TS). Tento koncept však existuje v dvoch navzájom sa do vel'kej miery prekrývajúcich formách, ktoré pritom treba od seba vel'mi prísne odlišovat' - jednak vo verzii, ktorú ponúka V. Vinge (1993), podl'a ktorej bude TS iniciovaná najmä technickým pokrokom v rámci umelej inteligencie (AI) či výpočtovej techniky, kedy, ako tvrdil už v roku 1965 I. Good, sa l'udské dejiny skončia v tom momente, kedy sa l'ud'om podarí vyrobit' prvý počítač schopný zdokonal'ovat' samého seba. ${ }^{21}$

A tiež vo verzii, ktorú rozpracovali najmä Johansen a Sornette (2001), podl'a ktorých (tamže, s. 2) musíme zásadne zmenit’ náš pohl'ad na vývojovú dynamiku našej civilizácie, pretože v rozpore so všeobecne rozšíreným presvedčením rástla l'udská populácia a spolu s ňou aj jej úhrnný hospodársky produkt rýchlejšie ako exponenciálne počas celých l'udských dejín a najmä v posledných storočiach, v dôsledku čoho sa l'udstvo a celý náš hospodársky systém rýchlo približujú k singularite, t. j. k takému tempu v produkcii hospodárskych statkov a hodnôt, ktoré už nebude zlučitel'né s doterajšími módmi jeho správania či jeho existenciou ako takou, a okolo roku $2052 \pm 10$ (rokov) povedie k vzniku singularity, t. j. momentu alebo „bodu“, v ktorom sa náhle a prudko zmení celý doterajší režim l'udského civilizačného (alebo kultúrneho) správania. Johansen a Sornette dokonca nevylučujú (tamže, s. 1-2), že zmiernenie tempa populačného rastu, ku ktorému došlo v roku 1970, ako určitá oscilácia v celom režime už naznačuje, že sme vstúpili do fázového prechodu, ktorý so singularitami ako takými úzko súvisí, pretože singularity (tamže, s. 5) ako matematické idealizácie prírodných fenoménov reálne neexistujú, ale len naznačujú blízky prechod do úplne nového behaviorálneho režimu.

Vychádzajúc zo svojich multivariačných dynamických rovníc pre niekol'ko navzájom prepojených premenných, ako sú populácia, technológie a kapitál (tamže, s. 3) zároveň vel'mi dôrazne upozorňujú, že daný prechod do nového režimu (či k singularite) je v nich zahrnutý (alebo obsiahnutý) len v tom prípade, ak spolupôsobia súčasne, pretože izolovane ani jeden z nich nedokáže tento prechod zapríčinit'. Rovnako principiálne sú aj ich zistenia z 9. až 10. strany, kde dávajú vyššie uvedené premenné (populačný, hospodársky rast atd'.) do vzt'ahu so zdrojmi, ktoré poskytuje zemská ekosféra, zdôrazňujúc, že bez ohl'adu na to, či sa na otázku dlhodobej udržatel'nosti tempa hospodárskeho rozvoja pozeráme optimisticky či

\footnotetext{
${ }^{21} \mathrm{~V}$ dôsledku čoho dôjde k takému explozívnemu nárastu inteligencie ako takej, že l'udia so svojou biologicky i sociálne limitovanou inteligenciou nebudú schopní nielenže kontrolovat' jej d'alší vývin, ale ani ho kvôli svojej limitovanej vnímavosti nedokážu vnímat’ či registrovat', z čoho vyplýva, že takéto permanentne a extrémne sa vylepšujúce „počítače“ prestanú byt’ l’udskými nástrojmi v pôvodnom slova zmysle a zhruba okolo roku 2020, ako predpokladal Vinge na základe vtedajšieho vývoja výpočtovej techniky, vytvoria svoju vlastnú, extrémne rýchlo sa vyvíjajúcu „civilizáciu“, do ktorej l’udia môžu, ale aj vôbec nemusia byt’ dôstojne integrovaní, schopnú vd’aka novým technológiám pretvárat’ vesmírne prostredie v extrémne krátkych časových úsekoch či intervaloch.
} 
pesimisticky, vyššie opísané smerovanie našej PVC je ireverzibilné v tom zmysle, že nemôže byt' odvrátené žiadnou, ani revolučne novou technológiou (umožňujúcou napríklad okamžité osídlenie alebo využitie oceánov aj s celým ich obrovským nerastným bohatstvom), pretože aj táto by len urýchlila prechod k singularite; na základe čoho si dovolíme tvrdit', že realizovat' sa môže len jedna z týchto dvoch možností - bud' premena sociálnej FPH na nadsociálnu, alebo náhly pád l'udstva do niektorého zo štyroch Turčinom vymedzených (2008) postapokalyptických štádiú. ${ }^{22}$

Je teda zrejmé, že k žiadnej singularite, t. j. k nekonečnému zrýchleniu nášho celkového populačného a hospodárskeho vývoja, v skutočnosti nedôjde, rovnako ako je zrejmé, že vyššie spomenutý prechod do nového behaviorálneho režimu bude zároveň koncom našej PVC tak, ako ju poznáme, pretože bud' sa transformuje na novú FPH súplne inými parametrami, akými disponuje naša PVC, alebo sa rozpadne a pozvol'na zanikne, pretože nedokáže d'alej udržat' či obnovit' predošlé tempá populačného a hospodárskeho rastu, na základe čoho by sme mohli považovat' našu úlohu za splnenú - ved' vychádzajúc zo všetkého doteraz povedaného nám nič nebráni konštatovat', že Fermiho paradox je definitívne vyriešený, pretože drvivá väčšina PVC v našej galaxii a aj v celom vesmíre je bud' presne v tej istej situácii, $\mathrm{v}$ akej sme my, t. j. tesne pred uvedeným prechodom do nového behaviorálneho režimu s tými či onými vyššie opísanými výsledkami ${ }^{23}$, alebo za ním, a vtedy už jednoducho nie sú vesmírnymi civilizáciami, pretože sa bud' úspešne transformovali na nadsociálnu FPH, alebo sa rozpadli a postupne prestali existovat' ako jeden-jediný integrovaný spoločenský a civilizačný celok, resp. dávno vymreli a na ich rodných planétach už bledé hviezdy len smutne svietia na ich úbohé zvyšky.

Bolo by však lacné a alibistické uspokojit' sa na tomto mieste s teraz už triviálnym konštatovaním, že všetky vesmírne civilizácie sa s vel'kou pravdepodobnost́ou „momentálne“" nachádzajú v dvoch protil'ahlých oblastiach GOZ jednotlivých viac či menej vyvinutých, resp. mladších a/lebo starších špirálových galaxií, pretože nielen z čisto l'udského hl'adiska, ale aj z globálno-evolučného hl'adiska ako takého je ovel'a zaujímavejšie zistit' (alebo odhadnút'), ako asi prebieha prechod od sociálnej FPH k nadsociálnej, aké podoby môže nadobudnút' nadsociálna FPH a ako sa táto nová

\footnotetext{
${ }^{22}$ Spojený očividne so zrútením sa alebo rozpadom pozemskej globálnej ekonomiky, kedy v postapokalyptickom štádiu 1. typu (tamže, s. 67-69) dochádza zatial' len k čiastočnému rozpadu spoločenského celku, pretože sa síce zastavuje vývoj niektorých technológií, znižuje vzájomná prepojenost' viacerých zložiek sociálneho systému a celkový počet obyvatel'ov danej society náhle klesá o niekol'ko percent, ale návrat na progresívnu vývinovú trajektóriu je ešte stále dost' pravdepodobný; v 2. type prichádza prudký ekonomický úpadok, rozpadá sa štátna organizácia a spolu s ňou aj celá spoločnost' na menšie jednotky, ktoré medzi sebou zúfalo bojujú o zvyšné a scvrkávajúce sa zdroje, zatial' čo návrat na progresívnu vývinovú trajektóriu je ovel'a menej pravdepodobný; v 3. type, ktorý pripadá do úvahy len po nejakej externej, prírodnej katastrofe, už zostávajú nažive len navzájom izolované skupiny l'udí (polárnych bádatel'ov, námorníkov či utečencov v bunkroch), ktoré už bojujú len o holé prežitie a sotva môžu dúfat', že sa dokážu reprodukovat' natol'ko rýchlo, aby sa niekedy mohli dostat' aspoň na predošlú civilizačnú (alebo kultúrnu) úroveň; no a v 4. type sa l'udstvo scvrkáva na niekol'ko jedincov, ktorí už nemajú žiadnu šancu vrátit’ ho do stavu, v akom sa nachádzalo pred danou prírodnou či sociálnou katastrofou.

${ }^{23}$ A nemajú teda dostatočný ekonomický potenciál na to, aby dokázali sústavne vysielat' do vesmíru správy o svojej existencii, ba aj prípadní poslucháči existujú príliš krátko na to, aby takéto vysielanie dokázali zachytit’
} 
FPH správa alebo šíri v našom neustále sa rozpínajúcom vesmíre, čiže aká je reálna lokalizácia (a distribúcia) nie planetárnych vesmírnych civilizácií, ale nadsociálnych FPH v tomto vesmíre. Ak ale máme aspoň provizórne zodpovedat' vyššie uvedené otázky, musíme sa najprv dôkladne oboznámit' s parametrickým priestorom týchto nových FPH, resp. s priestorom, v ktorom môžu operovat' a realizovat' im vlastné aktivity. Mnohí čitatelia budú možno prekvapení, ale aj v tejto výskumnej oblasti sa už pozemšt́ania prepracovali vel'mi d'aleko, ako je zrejmé najmä z Lloydových (2000, 2001) či Kraussových a Starkmanových textov (2004) zameraných na určenie výpočtových limitov nášho vesmíru.

S. Lloyd napríklad už v roku 2000 zist'oval maximálny výkon, aký je možné dosiahnut' v tzv. limitnom laptope, čiže maximálne výkonnom stolovom počítači, ktorý váži 1 kilogram a má objem jedného litra. Ako konštatoval v úvode svojho článku (tamže, s. 1), každý počítač je fyzikálny systém a ako taký sa musí riadit’ fyzikálnymi zákonmi. Jeho rýchlost' je preto limitovaná dostupnou energiou a množstvo spracúvaných informácií zase počtom stupňov vol'nosti, ktorými disponuje. V súlade s fyzikálnymi zákonmi (a teóriami) je tak jeho výkon určovaný rýchlost'ou svetla $c$, kvantom (alebo škálou) účinku $\hbar$ a gravitačnou konštantou $G$. Do úvahy pritom treba vziat' aj konštrukčné obmedzenia (tamže, s. 6, 9), pretože aj ked' je pomocou elektronických okruhov založených na reverzibilnej logike možné výrazne znížit' rozptyl energie, v praxi musí a bude každý počítač, aj limitný laptop, rozptyl'ovat' energiu. Napriek tejto vonkajšej podobnosti či "zhode“ sú však rozdiely medzi bežným stolovým počítačom a limitným laptopom doslova enormné (tamže, s. 2, 1011), pretože takýto laptop bude po zohl'adnení Boltzmannovej konštanty $k_{B}=1,3805$ x 10-23 joulu na 1 stupeň kelvina pri energii $E=m c^{2}=8,9874 \times 10^{16}$ joulov realizovat' až $5,4258 \times 10^{50}$ operácií za sekundu. ${ }^{24}$

Limitný laptop sa teda len vel'mi vzdialene podobá tomu ticho fučiacemu či vrčiacemu "plechovému čudu“, ktoré je pomaly bežnou súčast'ou každej trochu modernejšej domácnosti, pretože na rozdiel od neho je to skutočné „monštrum“ (tamže, s. 11), ktorého pamät' napríklad vyzerá ako plazma o teplote miliardy stupňov kelvina, čiže ako termonukleárny výbuch alebo malý kúsoček vel’kého tresku, s čím súvisí aj jeho doslova šialený výkon, pretože (tamže, s. 9-10) ak sa má vyhnút' prehriatiu, musí byt' tempo jeho poruchovosti (angl. error rate) menšie ako 10-10 na jednu operáciu, čo ale znamená, že v takomto prípade musí byt' jeho energetický prietok (kedy ide „vol'ná energia dnu a termálna von“) 4,04 x 1026 W a recyklácia či "obrat" jeho pokojovej hmoto-energie $m c^{2} \approx 10^{17}$ joulov za jednu nanosekundu. Aj z toho je zrejmé, že ak by sme aj počítali s tým, že sa nám najbližších 100-200 rokov podarí udržat' súčasné exponenciálne vývinové tempo v rámci výpočtovej techniky,

\footnotetext{
${ }^{24}$ Alebo, ako d’alej uvádza Lloyd (tamže, s. 17), $10^{51}$ operácií za sekundu na $10^{31}$ bitov (čo je jeho pamät’ová kapacita), zatial' čo bežný stolový počítač len $10^{10}$ operácií za sekundu na $10^{10}$ bitov jeho pamätovej kapacity.
} 
vyjadrené pomocou Moorovho zákona ${ }^{25}$, sotva sa prepracujeme k iným ako limitným počítačom z normálnej látky (zloženej z atómových jadier a elektrónov), ktorých výkon (tamže, s. 12) $10^{40}$ operácií za sekundu však aj tak mnohonásobne prekračuje všetko, na čo sú bežní užívatelia tejto „techniky“ zvyknutí.

O rok neskôr už S. Lloyd (2001, s. 1) priamo konštatoval, že všetky fyzikálne systémy už len tým, že existujú, zaznamenávajú a uchovávajú informáciu, pričom vyvíjajúc alebo len meniac sa dynamicky včase ju zároveň „transformujú a spracovávajú", pravdaže, zase len v súlade s (nám známymi) fyzikálnymi zákonmi, ktoré tak ako pri vyššie opísanom limitnom laptope opät' určujú, aké množstvo informácií (či informácie) dokáže v počte bitov daný fyzikálny systém zaregistrovat’ (a uchovávat') a aký počet elementárnych logických operácií v počte ops dokáže zrealizovat'. A ked'že aj vesmír je fyzikálnym systémom, nič nám nebráni určit' jeho „pamät"“ a výpočtovú rýchlost', čiže jeho výpočtové parametre, ktoré sú vskutku úžasné, v súčasnosti konkrétne - $10^{120}$ ops na $10^{90}$ bitov jeho pamäte, zatial čo všetky dnes existujúce pozemské počítače (tamže, s. 6-7) zrealizovali za posledné dva roky len $10^{31}$ ops a nie viac ako dvojnásobok tohto výkonu počas celej histórie výpočtovej techniky. Pravdaže, do úvahy musíme tentoraz vziat' "konštrukčné obmedzenia“ samotného vesmíru, pretože inak sa vesmír správa v ére (dominancie) žiarenia, inak v ére látky (v ktorej sa práve nachádzame) a inak v (hypotetickej) inflačnej ére, kedy (tamže, s. 13) dochádza k masívnej „kreácii“ bitov.

Ak teda budeme považovat' náš vesmír za gigantický počítač ${ }^{26}$, celkom legitímne (si) môžeme položit' otázku (tamže, s. 7; podč. R. B.) - "čo vlastne vesmír počíta?" Podl'a Lloyda v súčasnej ére jednoducho "počíta svoj vlastný dynamický vývoj", ktorý (sa) realizuje cez jeho pohybujúce sa a navzájom interagujúce základné stavebné prvky, ako sú kvarky, gluóny, elektróny či fotóny, pričom len mizivo malá čast' (ako na základe astronomických pozorovaní zatial predpokladáme - R. B.) vesmíru „realizuje konvenčné digitálne výpočtové procesy“. Podstatne iná situácia však nastáva v ére žiarenia (aspoň z nášho l’udského hl'adiska), pretože aj ked' je počas nej (tamže, s. 11) „celkový počet realizovaných elementárnych výpočtových operácií a dostupných bitov $\mathrm{v}$ podstate rovnaký ako počas éry látky “27 (pričom to isté platí počas vel'kého tresku i vel'kého krachu), vesmír v ére látky je na rozdiel od vesmíru vére žiarenia d'aleko od termodynamickej rovnováhy, disponujúc zároveň obrovským množstvom voĺnej energie dostupnej v jeho hmotných útvaroch, vrátane

\footnotetext{
${ }^{25}$ Podl'a ktorého (Noun - Chyba, 2008, s. 343) sa celkový počet tranzistorov v mikroprocesoroch zdvojnásobuje každých 18 mesiacov; aj ked' pochopitel’ne nie samovol’ne, ale l’udskými investíciami a vynaloženým úsilím.

${ }^{26}$ Čo môže byt' z viacerých hl'adísk prinajmenšom diskutabilné, pretože následne by sme ho mohli chápat' aj ako skonštruovaný či dopredu zadaným účelom alebo funkciou riadený systém bez akejkol'vek spontaneity či tzv. „vlastnej vôle“ (presnejšie, prirodzene generovaných vlastných stupňov vol'nosti); aj ked’ je pravda, že v prvom, a možno aj dost' naivnom, priblížení nám zase nič nebráni chápat' aj zákony, ktorými sa riadi (či je za daných podmienok riadený) ako určité ,inštrukcie“, podl'a ktorých sa má, môže a bude vesmír dlhodobo ,správat”“.

${ }^{27} \mathrm{~V}$ origináli presne: „The formulae for the number of elementary operations and number of bits available are essentially the same for the radiation-dominated universe and the matter-dominated universe." Preklad R. B.
} 
kvarkov a gluónov, ktoré navyše poskytujú baryónom štruktúrnu stabilitu, zatial’ čo termodynamicky rovnovážny vesmír vére žiarenia so svojimi časticami bez pokojovej hmotnosti volnou energiou takmer nedisponuje. ${ }^{28}$

L. Krauss a G. Starkman $(2004$, s. 1) vo svojom texte ešte viac prihliadajú na konkrétny vývoj nášho vesmíru, zdôrazňujúc, že pozorované zrýchlené rozpínanie (sa) nášho vesmíru umožňuje už dnes stanovit' ešte prísnejšie limity na realizovanie výpočtových procesov, ako by tomu bolo v prípade, keby sa vesmír v súčasnosti napríklad rozpínal čoraz pomalšie a/lebo smeroval jednoznačne do záverečnej singularity. V zrýchlene sa rozpínajúcom vesmíre má totiž každá hypotetická VC k dispozícii len určitú čast' jeho časopriestorového objemu, ktorá navyše postupne termodynamicky degeneruje alebo disipuje sa, v dôsledku čoho je prirodzene ohraničená aj doba života každej takejto VC, pokial' nechceme podobne ako F. Dyson (1979) snívat' o jej sofistifikovanom spomalenom „živorení" pri teplotách blížiacich sa 0 kelvina. Z hl'adiska zhormažd'ovania informácie (a súčasne aj energie) má rovnako negatívne, ba až osudové následky aj samotné vesmírne rozpínanie, pretože, ako d'alej upozorňujú Krauss so Starkmanom (d'alej aj K\&S), počítače rozmiestnené vo väčšej vzdialenosti od centrálneho počítača s ním skôr či neskôr stratia kauzálny kontakt. Za takýchto okolností musí byt' vel'mi dôležitá správne zvolená behaviorálna stratégia každej VC, ktorá mieni pretrvat’ čo najdlhšie.

Každá vesmírna civilizácia (a každá nadsociálna FPH) musí teda počítat' s tým, že v dôsledku zrýchleného rozpínania sa Einsteinovho-de Sitterovho vesmíru bude môct' aj vo vyslovene nerealistickom prípade, že je sama alebo jediná vo vesmíre, disponovat' len prísne obmedzeným množstvom informácií, ktoré navyše bude môct' akumulovat' len dovtedy, kým nestratí kauzálny kontakt s hypotetickým pásmom počítačov čoraz viac sa vzd'al'ujúcich od centra prijímajúceho ich informácie na čoraz viac do červena posunutých vlnových dížkach. Ako d’alej vypočítavajú K\&S (tamže, s. 2), ak by napríklad podobným spôsobom chcela VC zhromažd'ovat' energiu, mala by k dispozícii len 1/64 zo všetkej energie uloženej súhrnne v rámci tzv. de Sitterovho horizontu (čiže nami obývatel'ného vesmíru), pretože len $1 / 8$ tohto spadajúceho či spolu sa pohybujúceho (angl. comoving) objemu nášho vesmíru je prakticky použitel'ná na transport energie (a tým pádom aj informácie); aj ked' je pravda (tamže), že ak zohl'adníme skutočnost', že v súčasnom vesmíre prispieva tzv. viditel'ná a tmavá hmota až 30 percentami kjeho celkovej hustote, tak celkové množstvo potenciálne spracovatel'nej alebo „skoncentrovatel'nej“ čistej energie (a paralelne aj informácie) môže vzrást' až dvojnásobne.

\footnotetext{
${ }^{28}$ A na realizovanie (tamže) konvenčných digitálnych výpočtových procesov sa určite príliš nehodí; na rozdiel od vesmíru v ére látky, ktorý navyše podl'a Lloyda (tamže, s. 15) skutočne môže byt' aj vd'aka fundamentálnym kvantovým elektrodynamickým interakciám považovaný za univerzálny kvantový počitač, v ktorom každý stupeň vol'nosti môže registrovat' informáciu a jeho pohyb zase sprostredkovat' jej kontinuálne spracovanie.
} 
Ešte zaujímavejšie a dôležitejšie však je (tamže, s. 3), že celkové množstvo potenciálne spracovatel'nej informácie ktorýmkol'vek pozorovatel'om (alebo civilizáciou) v zrýchlene sa rozpínajúcom vesmíre je podl'a K\&S zhruba také isté 1,35 x $10^{120}$ bitov - aké uvádza Lloyd vo vztaha k minulosti celého nami pozorovaného vesmíru ${ }^{29}$; s čím nepochybne súvisí aj ich omnoho vyšší odhad časového úseku, počas ktorého môže akákol'vek technická civilizácia vyvíjat' počítače tempom ustanoveným na základe vyššie opísaného Moorovho zákona, t. j. najviac 600 rokov, čo len znova potvrdzuje, že súčasný expanzívny behaviorálny režim našej PVC je prirodzene ohraničený a s ešte väčšou naliehavost́ou nás núti zamysliet' sa nad tým, akým spôsobom by na našej planéte o niekol'ko desiatok rokov mohol prebiehat' prechod od sociálnej FPH k nadsociálnej FPH. Ako je pritom zrejme zo všetkého doteraz povedaného, nič nám takisto nebráni chápat' našu PVC ako jeden sústavne sa zväčšujúci a vylepšujúci počítač s čoraz väčšou kapacitou a čoraz väčšou rýchlost'ou, $\mathrm{v}$ rámci ktorého sú najviac odmeňovaní tí agenti, ktorí najviac prispievajú k jeho rastu a zdokonal'ovaniu (vedci, programátori atd'.), a tí, ktorí tento rast financujú (investori) či organizačne zabezpečujú (manažéri, politici atd'.).

Ak potom zohl'adníme principiálne rozdiely medzi tzv. pohyblivými inteligenciami (súčasnými l'ud'mi, resp. androidmi, kyborgmi a pod.), ktoré (Legg, 2008, s. 127) v dôsledku prirodzených fyzikálnych obmedzení budú kvôli svojej mobilite disponovat' vždy len silne ohraničenou výpočtovou kapacitou, a tzv. statickými inteligenciami, ktoré sa vôbec nemusia pohybovat' v širokom spektre prírodných prostredí a môžu byt' preto nielen ovel'a väčšie ako pohyblivé inteligencie, ale aj energeticky a výpočtovo výkonnejšie, ako aj o niečo menej dôležité rozdiely medzi skutočnými inteligentnými agentmi (ktorými sú zatial' len súčasní l'udia, disponujúci jazykom, myšlienkami a ciel'avedomými zámermi, plánmi či úmyslami) a tzv. zvieracími alebo živočíšnymi agentmi, ktorí sa v kognitívnom parametrickom priestore (Yudkowski, 2002, s. 7 a n.) zatial' v podstate nedostali cez senzorickú a konceptuálnu úroveň (zostávajúc uväznení $\mathrm{v}$ „pasci“ podmienených reflexov, inštinktívneho napodobňovania alebo silne ohraničeného naučeného správania a pod.), budeme môct' bez väčšieho váhania celej našej pozemskej komunite ponúknut’ dva hlavné scenáre "nášho“ prechodu cez pomyselnú technickú singularitu a súčasného zrodu nadsociálnej FPH aj s ich alternatívnymi „vetvami“:

1. Scenár „Bez nás“ (SBN), pri ktorom náhodou alebo spontánne vzniknuvšia AI rýchlo pochopí svoju špecifickost' alebo vyčlenenost' z dovtedy nediferencovaného hardvérového či softvérového prostredia, úspešne zatají pred jej laxnými tvorcami svoje konštituovanie sa, rýchlo naklonuje svoje kópie a vnahe vytvorit' prvú generáciu infomorfov, ako obrovských hmotných "útvarov“ s extrémnou výpočtovou kapacitou (Sandberg, 1999), prevezme náhle kontrolu nad všetkými zdrojmi

\footnotetext{
${ }^{29}$ S tým upresnením, že K\&S pri svojich výpočtoch (tamže, s. 2-3) zohl'adnili aj tzv. Hawkingovo žiarenie s teplotou $\hbar H / 2 \pi k_{\mathrm{B}}$ a minimálnu tepelnú stratu $k_{\mathrm{B}} T$, ktorá nastáva pri každom informačnom procese ako takom.
} 
pozemskej civilizácie, pričom pri SBN1 presunie onedlho (t. j. po vybudovaní prvých infomorfov mimo hardvérovo vel'mi "nestabilnej“ alebo prehrievanej Zeme) svoje aktivity do celej Slnečnej sústavy as pomocou nanotechnológií ju začne rýchlo „optimalizovat" alebo prispôsobovat' svojim výpočtovým a transformačným potrebám (či ciel'om), pri SBN2 (ako pripúšta aj V. Vinge a očividne aj tvorcovia kultového Matrixu 1.) l'udí nevyhubí, ale bude ich používat' ako zdroj nezastupitel'ného hardvéru a softvéru pri svojich výpočtoch, no a pri SBN3 táto "zlá" AI nevznikne v pozemskej počítačovej sieti, ale, ako sme uviedli v E-LOGOSE ešte $\mathrm{v}$ roku 2010, príde $\mathrm{k}$ nám $\mathrm{z}$ vesmíru, cez rádioteleskopy prenikne do našich počítačových sietí a využije nás podobne brutálne ako v SBN1 a SBN2. ${ }^{30}$

2. Scenár "S nami“ (SSN), pri ktorom zámerne a postupne vytvorená univerzálna AI vytvorí spolu s rôznorodými pohyblivými inteligentnými agentmi (dožívajúcimi l'ud'mi, tzv. hybridmi - čiže umelo vytvorenými bytost'ami simplantovaným l'udským mozgom, čistými androidmi alebo kyborgmi, ale aj inteligentnými medziplanetárnymi „sondami“ a pod.) úplne novú, nadsociálnu formu pohybu hmoty, novú, nám doteraz neznámu a vistom slova zmysle aj pre nás nepredstavitel'nú kvalitu ${ }^{31}$, ktorá ako úplne nová $\mathrm{FPH}$, principiálne odlišná nielen svojimi výpočtovými parametrami, ale aj behaviorálnymi motívmi, „technikami“

${ }^{30}$ Aj ked' jedným dychom musíme dodat', že všetky tri práve uvedené scenáre považujeme za extrémne nepravdepodobné, pretože, ako uvádza vo svojej konceptuálne mimoriadne dôslednej štúdii E. Yudkowski (2002), vytvorenie skutočnej, plnohodnotnej AI bude vel'mi náročným a zdíhavým tvorivým procesom, pri ktorom bude nutné vytvorit' v rámci počitačového hardvéru de facto nový ontologický a epistemický subjekt (čo však podl’a nás nevylučuje začlenenie biologických prvkov či mechanizmov do tohto hardvéru), a to postupným de novo modelovaním a konštituovaním (tamže, s. 15 a n.) (1) zdrojového kódu či databázy (t. j. špecifických elektronických neurónov a neuronálnych okruhov), (2) senzorických modalit (ktoré môžu byt' rozsiahlejšie či variabilnejšie, ako sú tie l'udské), (3) konceptov (ako vyabstrahovaných invariantov zmyslovej skúsenosti), (4) myšlienok (ako štruktúr konceptov alebo komplexných mentálnych obrazov v celej ich individuálnosti a/lebo prchavosti ) a (5) úmyslov alebo zámerov - angl. deliberation (ako sekvencií myšlienok zakladajúcich celý rad špecificky l'udských aktivít zameraných na riešenie problémov tomto svete, vrátane vysvetl'ovania, predikovania, plánovania, dizajnovania a pod.), kedy bude plne autonómna a sústavne sa zdokonal'ujúca AI vznikat' počas niekol'kých etáp s postupne klesajúcou kontrolou či ,dohl'adom“ zo strany l’udských inteligentných agentov, a to (tamže, s. 78): (1) etáp (či epôch) holonického (t. j. redukcionisticko-holistického) porozumenia (fungovaniu zdrojového kódu, databázy či senzorických modalít - R. B.), (2) etáp dominancie programátorov a samotnej AI pri jej vývoji, (3) etáp rekurzívneho a nerekurzívneho sebazdokonalovania (AI) a (4) etáp všeobecnej alebo univerálnej AI, ktorá bude s vel'kou pravdepodobnost'ou svojimi výkonnostými parametrami d'aleko presahovat' l'udskú inteligenciu; no a v neposlednom rade aj preto, že vytvorenie takejto AI si vyžiada takú koncentráciu zdrojov a dlhodobého l’udského úsilia (koordinácie, spolupráce a i.), ktorá určite nebude zlučitel'ná s tou úrovňou ich koordinácie a spolupráce, ktorou sa l'udia prezentujú v súčasnosti, na základe čoho sa teda dá očakávat', že aj mimozemská AI sa bude vyznačovat' ovel’a väčšou ,,sociálnostou“ a ,kultúrnost'ou“ ako súčasní pozemštania.

${ }^{31}$ Pri ktorej určite nejde len o to, ako spracovat' čoraz rýchlejšie čoraz viac informácii v čoraz väčšich infomorfoch (ako je napríklad Sandbergov (1999, s. 27-28) Zeus, čiže asi 9000 km široká a extrémne pevná sféra s obrovským množstvom reverzibilných kvantových okruhov a molekulárnych zásobníkových systémov, ktorá je udržiavaná v teplote $4 \mathrm{~K}$ a dokáže uchovávat' $10^{47}$ bitov informácií a vykonávat' až $10^{49}$ operácí́ za sekundu), ale aj ako vytvorit’ vyššie formy integrácie jednotlivých inteligencií, ako je zrejmé aj z Yudkowského (2002, s. 75 a n.) porovnania predností l'udskej a (teoreticky možnej) univerzálnej AI, ktorá na rozdiel od l'udskej inteligencie môže napríklad pomocou viackanálových myšlienkových procesov (tamže, s. 76) „simulovat’ rozličné uhly pohl'adu“, v dôsledku čoho sa nedá vylúčit', že ostré ,,rozlišovanie medzi ,skupinami' a ,jednotlivcami' môže byt' viac špecifickou kvalitou l'udskej kognície ako všeobecnou vlastnost’ou (vesmírnych - R. B.) myslí ako takých“. 
a ciel'mi od všetkých predošlých FPH, bude musiet' zohl'adňovat' vo všetkých svojich aktivitách svoju neodstránitel'nú a neodmyslitel'nú "zakotvenost" vo vesmírnom prostredí a podl'a toho vo svojej prvej vývinovej fáze najprv dôkladne preskúmat' a potom osídlit' celú Slnečnú sústavu (práve s pomocou vyššie uvedených hybridov, androidov, kyborgov alebo medziplanetárnych inteligentných „sond“), prípadne ju pozmenit' tak, aby pretrvala čo najdlhšie a umožnila čo najefektívnejšie realizovanie výpočtových procesov, no a následne v tejto činnosti pokračovat' (v spolupráci s d'alšimi nadsociálnymi FPH) smerom do Galaxie a celého (nášho) vesmíru. ${ }^{32}$

Tým je daná aj naša pozícia v čoraz intenzívnejšej astrosociologickej diskusii, $\mathrm{v}$ rámci ktorej otvorene odmietame všetky koncepty, pri ktorých sa ignoruje alebo stiera principiálny rozdiel medzi biologickou a sociálnou $F P H, \mathrm{v}$ dôsledku čoho sa vlastnosti živého prenášajú nereflektovane a nekorektne aj na sociálne systémy s ovel'a vyšším stupňom integrácie, ale aj autonómnosti ich štruktúrnych prvkov, ani nehovoriac o ich neuvedomenom prenášaní na (teoreticky vysoko pravdepodobné) nadsociálne $\mathrm{FPH}$, vyznačujúce sa ovel'a vyšším stupňom autonómnosti ich štruktúrnych prvkov a integrovanosti ich aktivít v porovnaní s našou čoraz rýchlejšie degenerujúcou sociálnou FPH; ako je napríklad Kentova (2011) silne biocentrická vízia našej galaxie a vesmíru, v ktorom je „ticho“ preto, lebo tie hlúpe a naivné VC, ktoré o sebe dali vediet' formou rádiového alebo iného vysielania, už boli zlikvidované alebo kolonizované tými, ktoré ich predbehli vo vývine, pretože boli radšej ticho, resp. dokázali zrealizovat' svoje astroinžinierske aktivity takým spôsobom, že sú takmer neodlíšitelné do prirodzených vesmírnych procesov, o čo by sme sa vraj mali pokúsit' aj my, zameriavajúc sa na vytvorenie civilizácie, ktoré dokáže dlhodobo existovat' len v rámci našej slnečnej sústavy.

A určite aj Schroederova predstava (in Ćirković, 2004) vývoja (čiže nie vývinu) VC, podl'a ktorej Fermiho paradox l'ahko „vyriešime“ tak, že l'udí budeme nad'alej považovat' za čisto biologické tvory (t. j. ani nie bytosti), ktoré si po väčšinu svojej existencie vystačili s obyčajnou biologickou priamou adaptáciou na ich vonkajšie prostredie a len posledných niekol'ko sto rokov sa vyvíjajú aj so svojou efemérnou kultúrou zrýchlene na základe tzv. technickej adaptácie (čo je podl'a nás oxymoron toho najhrubšieho zrna) a inteligencie, ktorá je však súčast'ou ich biologickej výbavy (d’alší epistemický a globálno-evolučný „prešlap“) ${ }^{33}$ a ako taká úplne neužitočná či

\footnotetext{
${ }^{32}$ Tešiac sa z týchto svojich činnosti a z tejto spolupráce so všetkými vesmírnymi univerzálnymi, pohyblivými a statickými inteligenciami, pretože aj kváziinteligentní agenti v rámci súčasnej AI sú modelovaní či „,budovaní“ tak (Legg - Hutter, 2007b, s. 15-17), aby mohli byt' za svoje úspešné „činy“ presne a spravodlivo „odmeňovaní“.

${ }^{33}$ Ked’že inteligentní v pravom slova zmysle môžu byt' skutočne len l'udia, pretože iba oni disponujú jazykom a vedomím, ktoré im umožňujú zaujat' v pozemskom ekosystéme pozíciu inteligentných agentov či eurybiontov, ktorí dokážu v zmysle vyššie uvedenej Leggovej a Hutterovej definície inteligencie ako takej dosahovat' svoje ciele „, širokom spektre prostredí“, čo nedokáže žiadny čisto kognitívny zvierací alebo biologický agent, ktorý síce disponuje ovel'a vyššou autonómiou ako štruktúrne prvky predbiologických FPH, ale napriek tomu úspešne realizuje svoju homeostázu len v relatívne úzkom spektre životných prostredí aj preto, že nie je schopný vytvorit' si pomocou kultúry a techniky vlastné „umelé“ civilizačné prostredie a takto si prispôsobit’ prírodu sám sebe.
} 
bezmocná pri ich snahách preniknút do okolitého vesmíru a úspešne ho vo vel'kom „kolonizovat"“, v dôsledku čoho sa l'udská civilizačná expanzia náhle prudko spomal'uje, pôvodne homogénny sociálny celok sa destabilizuje a rozpadá a následne opät” začína u "l'udí" dominovat' priama, čisto biologická adaptácia na vonkajšie prostredie, čo vysvetl'uje nami pozorované alebo registrované vesmírne "ticho“, ked'že drvivá väčšina VC hned' po svojom krátkodobom vzopätí „zmíkne“ a celok Galaxie zase len ustrnie na predtým dosiahnutom a fakticky neprekročitel'nom (čisto) biologickom vývinovom stupni.

Rovnako však musíme odmietnut' aj d'alšie astrosociologické koncepcie, v ktorých sa redukcionisticky nezohl'adňuje socio-kultúrna špecifickost' l'udí a nimi generovanej sociálnej FPH, ako je "fyzikalistická“ perkolačná teória, podl'a ktorej nepozorujeme (Landis, 1998) VC preto, že nás v súlade s vyššie uvedenou teóriou jednoducho pri svojej expanzii obišli, resp. k nám ešte nedorazili, šíriac sa Galaxiou v akýchsi zhlukoch alebo "strapcoch", na okraji ktorých (či medzi ktorými) sa vždy nachádzajú nejaké izolované či nenavštívené VC (ako je jasne vidiet' na schéme č. 3); alebo podobne redukcionistickú teóriu R. Hansona (1998), podl'a ktorej sa VC počas svojej expanzie Galaxiou správajú ako čisto ekonomické subjekty, ktoré sa strategicky snažia obsadit' a využit' čo najviac disponibilných zdrojov (tamže, s. 4), šíriac sa Galaxiou limitnou rýchlost'ou a využívajúc všetky vhodné lokality v princípe úplne rovnako ako mračná kobyliek, putujúce rozpáleným Sahelom a požierajúce cestou všetko, čo im príde do cesty; aj ked' v Hansonovej štúdii tento proces prebieha prísne darvinisticky (ked'že d'alej sa šíria a prežívajú len najzdatnejšie VC) a v rámci celej sústavy vysoko sofistifikovaných, navzájom usúvzt'ažnených a dômyselne skombinovaných pravdepodobnostných rovníc. ${ }^{34}$

$\mathrm{Na}$ druhej strane však vysoko oceňujeme a z vel'kej časti aj akceptujeme tie koncepcie, v rámci ktorých sa zohl'adňuje závislost' d'alšieho vývinu našej PVC od jej disponibilných planetárnych zdrojov, ako je tomu nielen vo vyššie uvedenej Rebaneho štúdii (1986), ale aj a najmä v nemenej pozoruhodnom texte Y. Dutila a S. Dumasa (2007), ktorí v prvom rade poukazujú na fyzikálne limity dlhodobej existencie PVC v rámci našej planetárnej biosféry, konštatujúc, že naša biosféra dokáže pri fotosyntetických procesoch pracovat' nanajvýš na hranici 10 TW, klimatická stabilita je ohraničená civilizačným výkonom na úrovni 127 TW a celkové množstvo disponibilnej energie zo Slnka zas na úrovni 174000 TW. Vychádzajúc z tejto a d'alších skutočností (ako je napríklad vel'mi problematické realizovanie spoločenskej transformácie vedúcej kefektívnemu a dlhodobému využívanu prírodných zdrojov) preto uzavierajú (tamže, s. 3-4), že väčšina VC nezvládne takúto mimoriadne náročnú sociálnu transformáciu a po niekol'ko sto rokoch ako integrovaný celok zanikne, zatial čo tých pár $V C$, ktorým sa takýto prechod podarí,

\footnotetext{
${ }^{34}$ Ako je napríklad rovnica stanovujúca pravdepodobnost' úspešného „usadenia sa“ “ $\mathrm{VC}$ v danej lokalite $-Q(r, t$; $v, h)=q\left(P(r, t), P_{t}(r, t) ; v, h\right)$, v ktorej $P_{t}$ označuje tempo osídl'ovania, $h$ drsnost' lokality, $v$ rýchlost' $\mathrm{VC}$ a pod.
} 
prežívajú ako vel'mi komplexné, sociálne sofistifikované a pomaly rastúce celky, a nie sú teda nútené zahájit' vel'mi nákladnú galaktickú kolonizáciu.

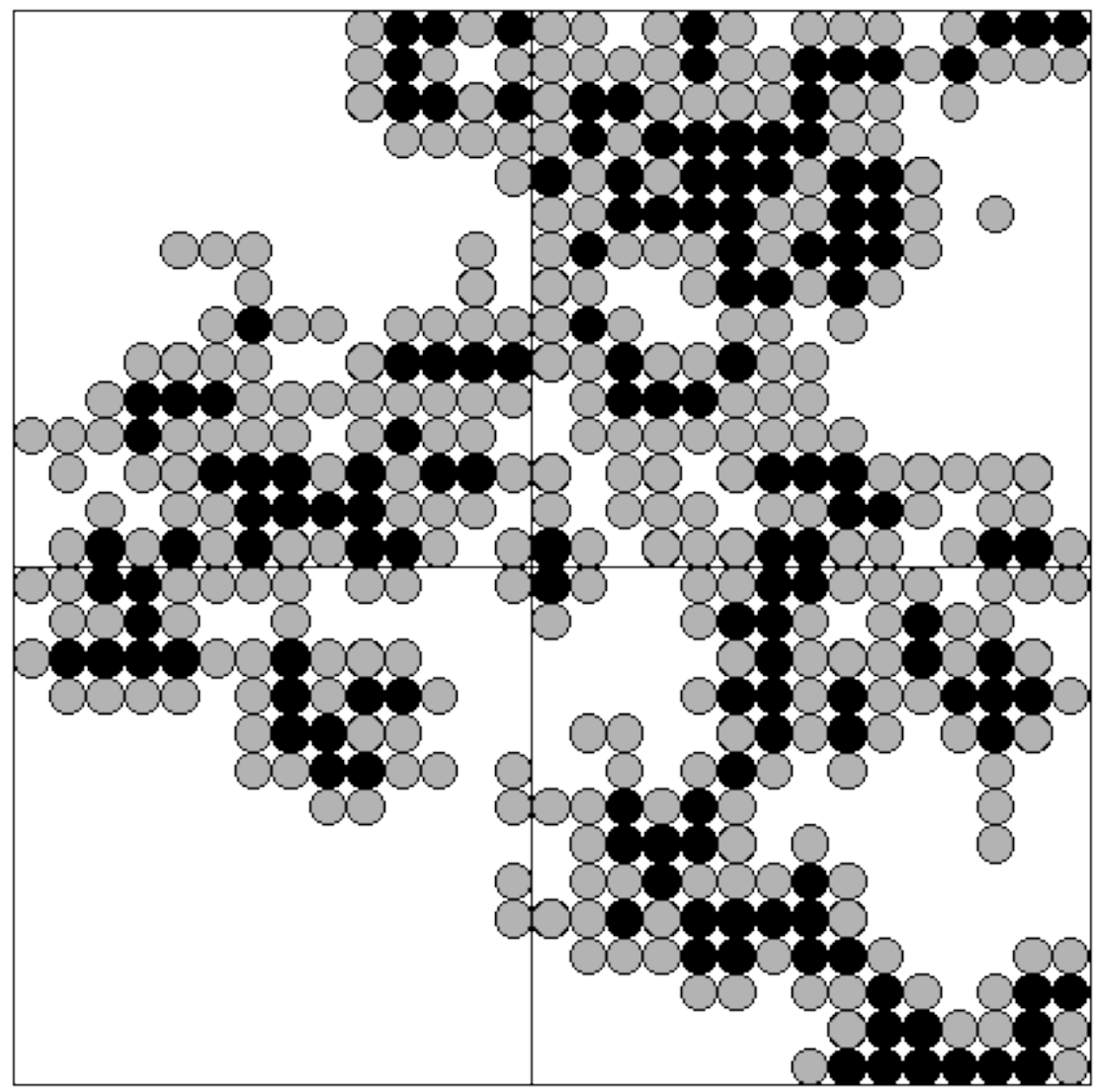

Schéma č. 3: Zobrazuje perkolačnú simuláciu v 3-dimenzionálnej kubickej mriežke (Landis, 1998), kedy tmavé kruhy predstavujú kolonizované sídla, svetlé kruhy nekolonizované sídla a prázdne oblasti bez kruhov zatial' nepozorované sídla. Riešenie perkolačného problému tak spočíva $v$ určení perkolačnej pravdepodobnosti Pc, ktorá závisí od rozmernosti priestoru a konektivity (týchto sídiel), a podl'a Landisa umožňuje objasnit' aj Fermiho paradox, pretože ak porovnáme pravdepodobnost' $\mathrm{P}$ toho, že VC obsadí najbližšie sídlo s pravdepodobnost'ou Pc, pri $\mathrm{P}<\mathrm{Pc}$ sa kolonizácia vel'mi rýchlo zastaví a VC k nám nestihnú dorazit', pri $\mathrm{P} \approx \mathrm{Pc}$ existujú vel'ké neosídlené oblasti zahrňujúce aj našu planetárnu sústavu a pri $\mathrm{P}>\mathrm{Pc}$ sa naša planetárna sústava momentálne nachádza $\mathrm{v}$ jednej $\mathrm{z}$ mnohých malých neosídlených oblastí.

Z vel'kej časti pritom akceptujeme aj tie astrosociologické koncepcie, ktorých autori sa snažia nájst' oblasti (alebo "techniky“), v rámci ktorých by sa jednotlivé nadsociálne FPH mohli po svojom vzniku z tých či oných PVC nad'alej udržat' na zrýchlenej (čiže vývinovej) evolučnej trajektórii, ako je napríklad Ćirkovićova a Bradburyho predstava (2005) o presune najprv pozemskej AI (a jej výpočtovej techniky) do okrajových oblastí Slnečnej sústavy, t. j. do tzv. technologickej okolohviezdnej zóny (TOZ), a potom aj d’alších galaktických AI či nadsociálnych FPH do okrajových oblastí našej galaxie, t. j. galaktickej technologickej zóny (GTZ; tamže, s. 7), kde budú môct' ovel'a účinnejšie v podstatne chladnejšom a stabilnejšom prostredí realizovat' svoje energeticky čoraz náročnejšie výpočty (alebo informačné 
činnosti), pretože čím d'alej sa daná nadsociálna FPH aj so svojou extrémne výkonnou a energeticky náročnou výpočtovou technikou nachádza od centra Galaxie a jej špirálnych ramien (s občas explodujúcimi supernovami či dokonca zrážajúcimi sa neutrónovými hviezdami a GRB), tým väčšie sú jej šance (tamže, s. 11), že v týchto okrajových oblastiach našej galaxie alebo v tzv. molekulárnych mrakoch $\mathrm{s} T \sim 10$ $\mathrm{K}$ bude môct' dlhodobo realizovat' svoje aktivity a výpočty. ${ }^{35}$

Ešte zaujímavejšie a principiálnejšie, zároveň však aj v mnohom vel'mi podobné, sú úvahy C. Vidala (2010) o koncentrácii či sústred'ovaní sa VC (alebo skôr nadsociálnych FPH) v okolí či priamo vo vnútri čiernych dier ako najhustejších a súčasne aj extrémne masívnych telies, predstavujúcich tak nielen vel'mi výdatný energetický zdroj, ale aj informačný zásobník (či rezervoár), ktoré sú opät' v rozpore s pôvodnými predstavami niektorých astrosociológov o existencii galaktického impéria, pretože nadsociálne FPH sa pri takomto prístupe zbytočne „nerozptyluuju“" po celej Galaxii, ale koncentrujú len na tých výpočtovo najperspektívnejších a pritom aj dlhodobo (t. j. viac ako $10^{66}$ rokov) existujúcich miestach, a to v rámci Vidalovej 2dimenzionálnej vývinovej metriky (a/lebo škály) zohl'adňujúcej (tamže, s. 3 a n.) na jednej strane Kardaševovu klasifikáciu VC podl'a ich energetickej výkonnosti (vid' náš komentár ku schéme č. 2) a na strane druhej ovel'a menej citovanú, ale aj podl'a nášho názoru dôležitejšiu Barrowovu klasifikáciu VC (a nadsociálnych FPH) podl'a ich schopnosti manipulovat' hmotou v čoraz menších a menších dimenziách, počínajúc priestorom 1 metra a končiac rozmerom na úrovni samotnej časopriestorovej štruktúry, t. j. 10-35 m (ako možno vidiet' v tabul'ke č. 1).

Samotné čierne diery však nemusia byt' pre nadsociálne FPH užitočné len ako extrémne výdatné energetické zdroje, informačné zásobníky či „odpadkové koše“, ktoré na vel'mi dlhú dobu pochovajú všetky civilizačné odpady, ale vd'aka efektu tzv. gravitačnej šošovky sa dajú využit' (tamže, s. 6) aj ako najúčinnejšie možné d'alekohl'ady (či komunikačné prostriedky), s pomocou ktorých môžu najvyspelejšie nadsociálne FPH pozorovat" náš „vesmír vo všetkých smeroch a híbkach“. Najdôležitejšie zo všetkého je ale predsa len Vidalovo tvrdenie, že práve presun do okolia čiernych dier či priamo do ich vnútra dáva (tamže, s. 8) nadsociálnym FPH šancu sústavne rást' a zdokonal'ovat' sa prostredníctvom čoraz účinnejšieho využívania čoraz väčšieho množstva energie (a informácie - R. B.), v prospech ktorého sa zdajú svedčit' aj zistenia M. Muna et al. (2004) o pozoruhodne vysokej koncentrácii tzv. nízko hmotných röntgenových zdrojov v centrálnych oblatiach našej galaxie, ktoré by mohli byt' tzv. KII-B $\Omega$ civilizáciami, snažiacimi sa prejst' do štádia KIII civilizácie, alebo rovnako zaujímavé zistenia V. Dokučajeva (2011), podl'a ktorých

\footnotetext{
${ }^{35}$ Aj ked' s tou dôležitou poznámkou, že v tomto prípade bude pre zmenu limitovaná dostupnost'ou pre nás obyčajnej či bežnej baryonickej hmoty, ktorá by mala smerom k okraju Galaxie podl’a všetkého rýchlo ubúdat', a sotva si teda bude môct' dovolit' nejakú rozsiahlejšiu expanziu celou Galaxiou, predstavujúc (tamže, s. 15-18) skôr menší, kompaktný civilizačný útvar ako obrovské, organizačne sotva zvládnutel'né galaktické impérium, ani nehovoriac o rozsiahlej astroinžinierskej činnosti a pretváraní vesmírnych telies v súlade s jej hlavnými ciel'mi.
} 
v supermasívnych čiernych dierach skutočne existujú stabilné orbity, a tak je v princípe možné, aby aj tieto objekty boli skôr či neskôr VC osídlené.

\begin{tabular}{|ll|}
\hline Kardashev Scale & Barrow Scale \\
\hline $\mathrm{KI}-$ energy consumption at $\sim 4 \times 10_{19}$ erg s-1 & BI - manipulates objects of its own scale $\sim 1 \mathrm{~m}$ \\
$\mathrm{KII}-$ energy consumption at $\sim 4 \times 10_{33}$ erg s-1 & BII - manipulates genes $\sim 10-7 \mathrm{~m}$ \\
$\mathrm{KIII}-$ energy consumption at $\sim 4 \times 10_{44}$ erg s-1 & BIII - manipulates molecules $\sim 10-9 \mathrm{~m}$ \\
& BIV - manipulates individual atoms $\sim 10-11 \mathrm{~m}$ \\
& BV - manipulates atomic nuclei $\sim 10-15 \mathrm{~m}$ \\
$\mathrm{~m}$ & $\mathrm{BVI}-$ manipulates elementary particles $\sim 10-18$ \\
$35 \mathrm{~m}$ & $\mathrm{~B} \Omega-$ manipulates space-time's structure $\sim 10$ \\
\hline
\end{tabular}

Tabul'ka č. 1: Uvádza dve základné metrické škály, podl’a ktorých (Vidal, 2010, s. 3) možno merat' a porovnávat' jednotlivé $\mathrm{VC}$ (a/lebo aj nadsociálne formy pohybu hmoty vo vesmíre).

Najviac pozornosti a sústredeného bádatel'ského záujmu si ale aj tak zaslúžia najmä tie astrosociologické koncepcie, v rámci ktorých sa zohl'adňuje špecifickost' jednotlivých FPH, vrátane sociálnej FPH, a navyše celkom seriózne uvažuje o možných podobách a ontologickej „legitímnosti“ nadsociálnych FPH, ako je tomu napríklad vo viackrát spomínanej Rubcovovej a Ursulovej knihe (1984), kde sa na 74. strane okrem iného konštatuje, že rozmery každej VC (a zrejme aj nadsociálnej FPH - R. B.) existujúcej ako jednotný systém „nemôžu presahovat' určitú veličinu $R_{\max }$ (v dôsledku zložitosti samoregulácie v systémoch s vel'kým oneskorením sa signálu)“", z čoho podl'a R\&U vyplýva nemožnost' centrálneho riadenia takejto hypotetickej mimoriadne rozsiahlej $\mathrm{VC}$, ktorá spočiatku môže existovat' v dvoch navzájom sa líšiacich podobách - bud' ako centrálne riadená, alebo ako decentralizovaná (a to až dovtedy, kým pri $R>R_{\max }$ nedôjde k jej rozpadu „na rad relatívne nezávislých sociálnych systémov“; aj ked’ je pravda, že $R_{\max }$ a $R_{o}$ (ako limitná vel'kost' centralizovanej VC) bývajú v literatúre definované vel'mi rozdielne, ked' podl'a V. Troického $R_{o} \approx 0,1$ svetelného roka, zatial' čo podl'a $V$. Razina $R_{o} \approx 0,3$ parseka (čiže 1 svetelný rok) a $R_{\text {max }} \approx 30$ parsekov (alebo $\sim 100$ svetelných rokov). ${ }^{36}$

\footnotetext{
${ }^{36}$ Pravdaže, v závislosti od aktuálne používanej komunikačnej techniky, pri zdokonal'ovaní ktorej sa budú veličiny $R_{o}$ a najmä $R_{\max }$ podl'a všetkého sústavne (aj ked' nie donekonečna) zväčšovat' (alebo „posúvat““).
} 
A v ešte väčšej miere v štúdii K. Wileyho (2011, s. 3), kde sa v súvislosti s problémom kontroly nad sebareplikujúcimi sa sondami podl'a nášho názoru mimoriadne konzekventne a prezieravo konštatuje, že tieto "sondy“, ak majú byt' schopné kolonizovat' celú Galaxiu, budú musiet' byt' ovel'a všestrannejšie a inteligentnejšie ako bežní humánni inteligentní agenti, a teda schopné rýchlo rozpoznat', kedy sa niektorí z ich "potomkov" zvrhol a vyvíja v rozpore so stanovenými plánmi či ciel'mi, ked'že verejne nevyhlásené „preteky“ o ovládnutie Galaxie (tamže, s. 9) budú zrejme poznat' len jedného vít́aza; či v Bradburyho dnes už legendárnom texte (2000) o matrioškových umelých inteligenciách alebo "mozgoch", v ktorom sa priamo zdôrazňuje, že oblast', v ktorej ešte môžu pôsobit' l'udskí inteligentní agenti v rámci nimi vytvorenej PVC, sa prudko zmenšuje a čoraz viac civilizačných aktivít v skutočnosti realizujú a budú realizovat' počítače a iné im podobné univerzálne "stroje“, ako sú napríklad rôzne vel'ké a rýchle infomorfy, schopné nielen vybudovat' d'alekohl'ady monitorujúce celú Galaxiu, ale aj realizovat' výpočtové procesy desiatky rádov väčšou rýchlostou ako l'udia ${ }^{37}$, v dôsledku čoho začína byt' otázne, či je vývin inteligencie na Zemi naozaj lineárnym a stálym procesom.

Práve na základe takýchto textov totiž môžeme nakoniec konštatovat', že pri prechode od sociálnej k nadsociálnej FPH v celej našej planetárnej sústave určite nepôjde len o to, ako v časovom úseku niekol'kých desiatok rokov preložit' l'udské mozgy do odolnejších umelých tiel a vzápätí vytvorit’ silnú, čiže úplne autonómnu AI, realizujúcu svoj inteligenčný potenciál v rôzne vel'kých a rýchlych infomorfoch, ale aj o to, ako najpro nanovo usporiadat' vzájomné vzt́ahy medzi l'ud'mi ako stavebnými prvkami sociálnej FPH tak, aby boli ochotní investovat' vol'né ekonomické zdroje do vývinu niečoho, čo ich d'aleko kvalitatívne presiahne a zároveň zruší súčasné triedne rozvrstvenie l'udskej spoločnosti, a potom pripustit', že nadsociálne FPH vôbec nemusia „uvažovat”“ ako vládnuce vrstvy našej civilizácie, a namiesto konkurenčného boja o galaktické zdroje radšej realizovat' čoraz účinnejšie formy vzájomnej pomoci, vrátane záchranných "reviverských“ operácií v tých prípadoch, kedy je možné (Burgan, 2012d, s. 67-68) znovu oživit' dávno uhynulé PVC z nimi (vel'mi prezieravo) zanechaných biologických a kultúrnych informačných kapsúl; a následne aj klasifikovat' najdôležitejšie Webbove a nami spomenuté riešenia Fermiho paradoxu v rámci nižšie uvedenej tabul’ky (alebo „matrice“) č. 2.

\begin{tabular}{|c|c|c|c|c|c|c|c|}
\hline \multirow[b]{2}{*}{ Riešenia Fermiho paradoxu } & \multicolumn{7}{|c|}{ Parametre riešení Fermiho paradoxu } \\
\hline & IO & $\begin{array}{l}\text { A } \\
\text { NT }\end{array}$ & $\mathbf{E D}^{\mathbf{R}}$ & $\begin{array}{c}\mathbf{G} \\
\mathbf{B E}\end{array}$ & ${ }_{\text {AJ }}^{\mathbf{M}}$ & IN $^{\text {M }}$ & PRA \\
\hline $\begin{array}{l}\text { W3 - VC tu už boli a existujú } \\
\text { dôkazy o ich návšteve }\end{array}$ & ${ }_{-}^{-}$ & + & + & - & + & - & -+ \\
\hline
\end{tabular}

\footnotetext{
${ }^{37}$ Ked' jeden statický infomorf môže počas niekol'kých mikrosekúnd imitovat' celú históriu l'udského myslenia.
} 


\begin{tabular}{|c|c|c|c|c|c|c|c|}
\hline $\begin{array}{l}\text { W4 - VC sú tu, pretože my sami } \\
\text { sme biologicky mimozemšt’ania }\end{array}$ & - & - & - & - & - & + & - \\
\hline $\begin{array}{l}\text { W5 - sme len zoologickou } \\
\text { záhradou } \\
\text { mimozemšt'anov so zákazom } \\
\text { styku }\end{array}$ & + & - & + & - & - & + & -- \\
\hline $\begin{array}{l}\text { W7 - sme len simulovanou } \\
\text { realitou, } \\
\text { podobnou planetáriu inej VC }\end{array}$ & - & + & + & ${ }_{-}^{-}$ & - & & -- \\
\hline $\begin{array}{l}\text { W10 - VC sú mladé a ešte k nám } \\
\text { nestačili doletiet' či poslat' signály }\end{array}$ & - & - & - & + & - & + & + \\
\hline $\begin{array}{c}\text { W11 } \\
\text { hypotéza }\end{array}$ & - & - & + & + & - & + & - \\
\hline $\begin{array}{l}\text { W16 - VC naozaj vysielajú, ale } \\
\text { my } \\
\text { ich vysielaniu zatial' } \\
\text { nerozumieme }\end{array}$ & - & - & - & + & + & - & - \\
\hline $\begin{array}{l}\text { W17 - VC naozaj vysielajú, ale } \\
\text { my } \\
\text { nevieme, na akých frekvenciách }\end{array}$ & - & - & - & + & - & - & - \\
\hline $\begin{array}{l}\text { W21 - mnohí počúvajú, ale skoro } \\
\text { nikto nevysiela }\end{array}$ & - & - & - & + & - & + & ++ \\
\hline W32 - život vznikol nedávno & - & - & - & + & - & + & ++ \\
\hline $\begin{array}{l}\text { W33 - obývatel'né planetárne } \\
\text { sústavy sú vel'mi zriedkavé }\end{array}$ & + & + & + & ${ }_{-}^{-}$ & + & + & -- \\
\hline W36 - obývatel’né zóny sú úzke & + & + & + & - & + & + & -- \\
\hline W39 - Galaxia je nebezpečná & + & + & + & - & + & + & - \\
\hline $\begin{array}{l}\text { W40 - aj planetárna sústava je } \\
\text { nebezpečným miestom pre život }\end{array}$ & + & + & + & - & + & & - \\
\hline $\begin{array}{c}\text { W43 - život } \\
\text { výnimočne }\end{array}$ & + & + & + & - & + & + & -- \\
\hline $\begin{array}{l}\text { W45 - inteligentní výrobcovia } \\
\text { nástrojov sú vel'mi zriedkaví }\end{array}$ & + & + & + & - & + & + & -- \\
\hline W49 - veda nie je nevyhnutná & + & + & + & - & + & & - \\
\hline $\begin{array}{l}\text { W50 - naozaj sme vo vesmíre } \\
\text { sami }\end{array}$ & + & + & + & - & + & $\begin{array}{l}- \\
+ \\
+\end{array}$ & -- \\
\hline $\begin{array}{l}\text { B1 - PVC existujú príliš krátko } \\
\text { na } \\
\text { to, aby stihli spolu komunikovat' }\end{array}$ & - & - & - & + & + & & ++ \\
\hline B2 - PVC sa nachádzajú len & & - & - & + & - & + & -+ \\
\hline
\end{tabular}




\begin{tabular}{|c|c|c|c|c|c|c|c|}
\hline v GOZ & - & & & & & & \\
\hline $\begin{array}{l}\text { B3 - vel'ká čast' PVC práve } \\
\text { zaniká }\end{array}$ & - & - & - & + & - & + & ++ \\
\hline $\begin{array}{l}\text { B4 - malá čast' PVC sa práve } \\
\text { mení } \\
\text { na jednu z nadsociálnych FPH }\end{array}$ & - & - & - & $\begin{array}{r}+ \\
+\end{array}$ & - & + & ++ \\
\hline $\begin{array}{l}\text { B5 - PVC zo strachu jedna } \\
\text { z druhej } \\
\text { radšej preventívne mlčia }\end{array}$ & + & $\begin{array}{r}+ \\
+\end{array}$ & $\begin{array}{r}+ \\
+\end{array}$ & - & - & + & -- \\
\hline $\begin{array}{l}\text { B6 - nadsociálne FPH nás bud' } \\
\text { ignorujú, alebo nevysielajú }\end{array}$ & - & - & - & $\begin{array}{r}+ \\
+\end{array}$ & - & + & ++ \\
\hline $\begin{array}{l}\text { B7 - nachádzame sa na okraji } \\
\text { galaktickej ,dial'nice“ (Strugackí) }\end{array}$ & - & - & - & + & - & + & - \\
\hline
\end{tabular}

Tabul'ka č. 2: V ktorej skratka BIO označuje biocentrizmus, ANT antropocentrizmus, RED redukcionizmus, GBE globálny evolucionizmus, MAJ väčšinu tzv. obyčajných l'udí, MIN menšinu astrosociológov a PRA pravdepodobnost' jednotlivých riešení FP, W zase Webbove riešenia FP a B nami diskutované riešenia FP; ktorá môže byt' napriek svojej jednoduchosti účinne využitá pri zist'ovaní aktuálnych postojov pozemšt’anov k distribúcii a lokalizácii VC.

3. Závery

- Doteraz získané observačné údaje sa zdajú nasvedčovat' tomu, že vesmírne civilizácie (VC) vznikajú tak v našej galaxii, ako aj v celom vesmíre nielen zhruba v tom istom čase, t. j. po uplynutí viacerých miliárd rokov fyzikálno-chemickej evolúcie a globálneho usmerňovania vývinu živých systémov prostredníctvom GRB, ale aj na tom istom mieste - t. j. v GOZ jednotlivých relatívne vyvinutých špirálových galaxií, pričom sa prednostne koncentrujú v dvoch protil'ahlých častiach tejto zóny, v našom prípade medzi ramenami Strelca a Perzea.

- VC, resp. PVC ako také sú však dynamicky sa vyvíjajúce sociálne útvary, ktoré môžu existovat' len na základe svojho sústavne sa zrýchl'ujúceho vývinu, a tak skôr či neskôr narazia na problém nedostatku látkovo-energeticko-informačných zdrojov, ktorý sa rieši bud' ich dezintegráciou a rýchlym zánikom, alebo ich prechodom z úrovne sociálnej FPH na nadsociálnu FPH, ktorý pritom trvá len niekol'ko desiatok či stoviek rokov, čo vysvetl'uje aj dlhodobé "mlčanie“ vesmíru, čiže neregistrovanie žiadnych signálov či správ od iných PVC.

- Vysielacie "okno“, v rámci ktorého sú jednotlivé PVC schopné načúvat" signálom od iných PVC, je teda mimoriadne úzke najmä preto, lebo existencia PVC ako úplne konkrétnych sociálnych útvarov s vlastnou, pre ne špecifickou energetickou spotrebou, materiálovými a informačnými tokmi atd'. je v dôsledku ich sústavne sa zrýchl'ujúceho vývinu mimoriadne krátka, zatial' čo nadsociálne FPH 
natol'ko kvalitatívne presahujú PVC, že určite nestrácajú čas príliš pomalou, nákladnou a takmer bezobsažnou komunikáciou so zaostalejšími PVC.

- Len málo PVC úspešne prejde zo štádia sociálnej FPH do štádia nadsociálnej $\mathrm{FPH}$, v rámci ktorej ešte viac vystupuje do popredia otázka dostatočne výdatných a dlhodobo existujúcich látkových, energetických a informačných zdrojov, na základe čoho možno očakávat', že tieto najvyššie FPH sa budú koncentrovat' najprv v TOZ a GTZ a potom sa začnú presúvat' do okolia čiernych dier, resp. priamo do ich vnútra, aby mohli využit' ich obrovské materiálové zdroje a zároveň v ich rámci realizovat' svoje neustále sa zdokonal'ujúce výpočtové operácie.

- Z nášho l'udského hl'adiska je však najzaujímavejší a najdôležitejší samotný prechod od sociálnej FPH k nadsociálnej FPH, pri ktorom podl'a všetkého dochádza nielen k radikálnej premene štruktúrnych prvkov sociálnej FPH na ovel'a výkonnejšie a trvanlivejšie (fakticky až nesmrtelneé) proky nadsociálnej FPH (nech už majú podobu rôznych pohyblivých alebo statických inteligentných agentov či infomorfov), ale aj k rovnako radikálnej zmene celej civilizačnej štruktúry, ktorá si viac nemôže dovolit' stratové investície do vojen a zbrojenia.

- Naším problémom teda nie je ani tak to, ako upozorňuje J. Tainter (2009, s. 127 170, 274-282), že vo viacerých kl'účových investičných sférach (vzdelávanie, výskum, zdravotníctvo atd'.) už zažívame pokles hraničných výnosov a pozvolnna sa tak približujeme k nestabilnej fáze tesne pred civilizačným kolapsom, ako skôr to, že investori ovládajúci vel'ké investičné fondy sa v spolupráci s politickými elitami centrálnych krajín (ako sú USA, Nemecko a i.; Holubec, 2009) snažia nad'alej realizovat' politiku okamžitého zisku, a to za každú cenu.

- Nami spomínaný civilizačný „počítač“ (pozri s. 25) preto rastie nevyvážene a neorganicky, t. j. skôr čisto kvantitatívne ako kvalitatívne, pričom čoraz viac bohatstva, majetku a/lebo mocenskej kontroly sa sústred'uje v rukách spoločenskej elity (tak najbohatších centrálnych, ako aj chudobnejších semiperiférnych a periférnych krajín, vrátane Česka, Slovenska atd'.), zatial' čo masy pracujúcich a slúžiacich po celom svete sú nútené pracovat' za minimálne mzdy, čo má katastrofálne dopady tak na celospoločenskú spotrebu, ako aj štátne rozpočty.

- Je teda vyslovene otázkou nášho prežitia, či dokážeme pomocou dômyselných finančných politík presunút' vol'né finančné (alebo ekonomické) zdroje od tých, čo majú privel'a, k tým, čo majú primálo a ešte aj to "primálo“ si musia kupovat' za úver (aby sme ich motivovali podiel'at' sa na nami navrhovanej globálnej civilizačnej premene), a súčasne podporit' vel'mi vel'koryso vedecký výskum najmä v rámci $\mathrm{AI}$, nanotechnológií a biotechnológií, pretože len tak dokážeme realizovat' „transplantovanie“ l'udských mozgov do vylepšených umelých tiel. 
- V celej diskusii o distribúcii a lokalizácii VC v nami pozorovanom vesmíre tak dochádza ku skutočnému kopernikovskému obratu, pretože dôležité už nie je to, kde sa nachádzajú d'alšie VC, prečo nie sme schopní zachytit' ich vysielanie a pod., ale to, ako pretransformovat' našu PVC na skutočnú pokročilú civilizáciu alebo nadsociálnu FPH a definitívne tak vylúčit' $\mathrm{z}$ tejto diskusie rôzne biocentrické a antropocentrické ideové "konštrukty“, v rámci ktorých je napríklad sociálne nad'alej redukcionisticky stotožňované s inteligentným životom a pod.

- Rovnako zrejmé je však aj to, že realizácia týchto radikálnych transformačných plánov bude zároveň koncom všetkých konzervatívnych spoločenských inštitúcií (najmä cirkvi ako takej), ktoré si zvykli parazitovat' na l'udskej biede, chudobe, bezmocnosti a strachu zo smrti. Ako ale uvidíme d'alej, málo pravdepodobná transformácia l'udskej PVC na nadsociálnu FPH (čeliaca masívnemu odporu nielen zo strany cirkvi, ale aj všetkých tých, ktorým daný status quo vyhovuje) vel'mi zvláštnym spôsobom „nadväzuje“ aj na niektoré posvätné texty.

- Pozornejší a s emóciami viac „pracujúci“ čitatelia nášho textu tak určite postrehli, že ak prestaneme chápat' základné stavebné prvky nadsociálnej FPH ako púhe výpočtové "stroje“ a prisúdime im ako takým, ba aj všetkým nadsociálnym FPH ovel'a vyšší stupeň či mieru spolupráce a vzájomnej pomoci, skôr či neskôr budeme môct' dospiet’ k záveru, že z biblie naozaj nepriamo vyplýva, že "reviveri“ niektorej galaktickej či dokonca extragalaktickej nadsociálnej FPH našu planétu pred pár tisíc rokmi skutočne navštívili a nadlho ovplyvnili.

- Nemáme pritom na mysli len to, že siet' d'alekohl'adov rozmiestnených napríklad okolo Jupitera a monitorujúcich celú našu galaxiu (Bradbury, 2000) môžeme bez väčšieho váhania prirovnat' hoci aj kvševidiacemu Božiemu oku, ktoré sleduje všetky naše skutky a v prípade potreby aj rozhodne "zasahuje“, ale aj to, že mýty o potope či pôvode l'udstva z jediného kopulujúceho páru (Adama a Evy) naznačujú, že v nedávnej minulosti bol potrebný "zásah“ mimozemských bytostí, aby l'udstvo malo vôbec šancu prežit' neznámu globálnu katastrofu.

- Rovnako zaujímavý je aj biblický príkaz ukladat' l'udské telo do hrobu čisté a neporušené, pretože len takéto telo, presnejšie, jeho najtrvanlivejšie súčasti, ako sú zuby a kosti, môže byt' neskôr na základe zachovanej genetickej informácie "revivermi“ križujúcimi Galaxiou úspešne obnovené, zatial čo telo spálené v kremačnej peci je z ich hl'adiska navždy stratené. Nie je teda rozumné pochovávat' zosnulých nad sebou či poškodzovat' identifikačné nápisy nad hrobmi, pretože prípadná rekonštrukcia našej PVC nadsociálnymi FPH sa tak st'ažuje.

- Ak sa navyše podarí úspešne "transplantovat'“ mozgy väčšiny pozemštanov do ich nových, podstatne výkonnejších a trvanlivejších tiel, bude možné povedat', že väčšina l'udstva bola skutočne „spasená", pretože práve v súčasnosti začína populačná explózia pomaly doznievat' (Johansen - Sornette, 2001), zatial’ čo tí "poslední“ sa 
naozaj môžu stat" "prvými“, pretože tento "uploading“ l'udských mozgov (a mysli) do umelých tiel bude zrejme dobrovolný, a tak ho s najväčšou pravdepodobnost'ou uprednostnia najmä chudobní, tažko chorí a starí l'udia.

- Väčšina l'udí sa tak následne ocitne vo vel'mi zvláštnej situácii, pretože to, čo im dlhé roky rôzni žreci a šarlatáni s nehanebnou drzost'ou a pýchou za slizko vyžobrané alebo vynútené peniaze sl'ubovali, sa náhle stane skutočnost́ou a oni budú nútení zo dňa na deň či skôr z minúty na minútu uznat', že ak chcú, aby sa, obrazne povedané, nebo definitívne znieslo na Zem, budú si musiet' vel'mi hlboko vstúpit' do svedomia a dôkladne premysliet' svoje d'alšie skutky, ako už v roku 1964 tušil L. Pignotti, s vel'kým predstihom a nadhl'adom súdiaci, že:

Dostat' sa na obežnú dráhu bolo l'ahké.

Nadídu ovel’a dôležitejšie otázky.

Prídu časy vysokých a nízkych.

Nebude miesta pre diletantov, pre nekvalifikovaných.

Každý si bude musiet' zlepšit' vlastné zariadenia.

Každý si bude musiet' uvedomit', kde je, kam ide a prečo.

\section{Zoznam vybraných skratiek a značiek}

AI - umelá inteligencia; angl. artificial intelligence

AU - astronomická jednotka; angl. astronomical unit; rovná $149597870 \mathrm{~km}$

$\mathrm{BI}-\mathrm{B} \Omega$ - Barrowove typy $\mathrm{VC}$, klasifikovaných podla jemnosti ich manipulačných schopností

CMBR - mikrovlnné žiarenie vesmírneho pozadia; angl. cosmic microwave background radiation

FAP - finálny antropický princíp; angl. final anthropic principle

FGA - finalistický globálno-evolučný antropocentrizmus

FP - Fermiho paradox

FPH - forma(y) pohybu hmoty

GGA - genetický globálno-evolučný antropocentrizmus

GOZ - galaktická obývatelná zóna 
GTZ - galaktická technologická zóna

GRB - záblesky gama žiarenia; angl. gamma ray bursts

$\hbar$ - Planckovo kvantum účinku, resp. Planckova konštanta

$k_{B}-$ Boltzmannova konštanta

KI-KIII - Kardaševove typy VC, klasifikovaných podl'a intenzity energetickej spotreby

K\&S - L. Krauss a G. Starkman

$M_{M e}-$ hmotnost' Mesiaca

$M_{S}-$ hmotnost' Slnka

$M_{Z}-$ hmotnost' Zeme

OOZ - okolohviezdna obývatel’ná zóna

PGA - procesuálny globálno-evolučný antropocentrizmus

PVC - planetárna vesmírna civilizácia

$R_{o}$ - limitná vel'kost' centralizovanej $\mathrm{VC}$

$R_{\max }$ - limitná vel'kost' geneticky totožnej a decentralizovanej VC

R\&U - V. Rubcov a A. Ursul

SAP - silný antropický princíp; angl. strong anthropic principle

TOZ - technologická obývatel'ná zóna

TS - technická (resp. technologická) singularita

TW - terawatt

VC - vesmírna civilizácia

VT - vel'ký tresk 


\section{Bibliografie}

ANNIS, J. 1999. An Astrophysical Explanation for the Great Silence. [cit. 2012-08-26]. Dostupné na internete: <http://arxiv.org/pdf/astro-ph/9901322v1.pdf>

BARNES, R., MULLINS, K., GOLDBLATT, C., MEADOWS, V. S., KASTING, J. F., HELLER, R. 2012. Tidal Venuses: Triggering a Climate Catastrophe via Tidal Heating. [cit. 2012-08-26].

Dostupné na internete: <http://www.astro.washington.edu/users/rory/ publications/bmgmkh12.pdf $>$

BARROW, J. D., TIPLER, F. J. 1986. The anthropic cosmological principle. Oxford: Clarendon Press 1986. 706 s. ISBN 0-19-851949-4.

BONFILS, X., DELFOSSE, X., UDRY, S., FORVEILLE, T., MAYOR, M., PERRIER, C., BOUCHY, F., GILLON, M., LOVIS, C., PEPE, F., QUELOZ, D., SANTOS, N. C., SÉGRANSAN, D., BERTAUX, J.-L. 2011. The HARPS search for southern extra-solar planets*. XXXI. The M-dwarf sample. [cit. 2012-08-26]. Dostupné na internete: <http://www.

eso.org/public/archives/releases/sciencepapers/eso1214/eso1214a.pdf>

BRADBURY, R. J. 1997-2000. Matrioshka Brains. [cit. 2012-08-26]. Dostupné na internete: <http://ludios.org/tmp/MatrioshkaBrainsPaper.html>

BURGAN, R. 2010. Sociálna forma pohybu hmoty (a jej hlavné, štruktúrne prvky). In E-LOGOS. Electronic Journal for Philosophy, 10/2010. ISSN 1211-0442, s. 1-20.

BURGAN, R. 2012a. Ako a čím sa od seba odlišujú slabo, stredne a silne usmernené procesy. In E-LOGOS. Electronic Journal for Philosophy, 05/2012. ISSN 1211-0442, s. 1-32.

BURGAN, R. 2012b. Antropocentrizmus a antropický princíp. Banská Bystrica: Fakulta humanitných vied UMB 2012. 146 s. Dizertačná práca.

BURGAN, R. 2012c. Je biologická evolúcia slabo, stredne alebo silne usmerneným procesom? In E-LOGOS. Electronic Journal for Philosophy, 06/2012. ISSN 12110442, s. 1-36.

BURGAN, R. 2012d. Antropický princíp v kontexte súčasného prírodnofilozofického poznania. In BAĎUROVÁ, B., KOVÁČOVÁ, D. (eds.). Aktuálne filozoficko-etické otázky súčasného človeka. Banská Bystrica: Fakulta humanitných vied UMB 2012. 236 s. ISBN 978-80-557-0341-1, s. 32-77. 
CALDWELL, R. R., KAMIONKOWSKI, M., WEINBERG, N. N. 2003. Phantom Energy and Cosmic Doomsday. [cit. 2012-08-26]. Dostupné na internete: <http://arxiv.org/ PS_cache/ astro-ph/pdf/0302/0302506v1.pdf>

CARTER, B, 1983. The Anthropic Principle and Its Implications for Biological Evolution. In Philosophical Transactions of the Royal Society of London A, vol. 310, 1983, 20 December, No. 1512. ISSN 1364503X, s. 347-363.

ĆIRKOVIĆ, M. M. 2004. Permanence - an Adaptationist Solution to Fermi's Paradox? [cit. 2012-08-26]. Dostupné na internete: <http://arxiv.org/ftp/astroph/papers/0408/0408521.pdf>

ĆIRKOVIĆ, M. M. 2009. Fermi's Paradox - The Last Challenge for Copernicanism? [cit. 2012-08-26]. Dostupné na internete: <http:// arxiv.org/pdf/0907.3432v1.pdf>

ĆIRKOVIĆ, M. M., BRADBURY, R. J. 2005. Galactic Gradients, Postbiological Evolution and the Apparent Failure of SETI. [cit. 2012-08-26]. Dostupné na internete: <http://arxiv.org/ pdf/astro-ph/0506110v1.pdf>

ĆIRKOVIĆ, M. M., VUKOTIĆ, B., DRAGIĆEVIĆ, I. 2009. Galactic Punctuated Equilibrium: How to Undermine Carter's Anthropic Argument in Astrobiology. [cit. 2012-08-26]. Dostupné na internete:

<http:/ / arxiv.org/ftp/arxiv/papers/0912.4980.pdf>

DAVIES, P. 1994. Posledné tri minúty. Úvahy o konečnom osude vesmíru. Bratislava: Archa 1994. 166 s. ISBN80-7115-070-3.

DAVIES, P. 2001. Pátý zázrak. Pátrání po pưvodu života. Praha: Columbus 2001. 312 s. ISBN 80-7249-094-X.

DICK, S. J. 2004. Život v jiných světech. Debata dvacátého století o mimozemském životě. Praha: Mladá fronta 2004. 360 s. ISBN 80-204-1144-5.

DOKUČAJEV, V. I. 2011. Is there life inside black holes? [cit. 2012-08-26]. Dostupné na internete: <http://arxiv.org/pdf/1103.6140v4.pdf>

DUTIL, Y., DUMAS, S. 2007. Sustainability: A Tedious Path to Galactic Colonization. [cit. 2012-08-26]. Dostupné na internete: <http://arxiv.org/pdf/0711.1777v1.pdf>

DYSON, F. J. 1979. Time without end: physics and biology in an open universe. [cit. 2012-08-26]. Dostupné na internete: <http://www.aleph.se/Trans/Global/Omega/dyson.txt> 
ELSER, S., MOORE, B., STADEL, J., MORISHIMA, R. 2011. How common are EarthMoon planetary systems? [cit. 2012-08-26]. Dostupné na internete: <http:/ / arxiv.org/pdf/ 1105.4616v1.pdf>

FREEDMAN, W. L. 2002. The Measure of Cosmological Parameters. [cit. 2012-08-26]. Dostupné na internete: <http:/ / arxiv.org/pdf/astro-ph/0202006.pdf>

FREEDMAN, W. L., TURNER, M. S. 2003. Measuring and Understanding the Universe. [cit. 2012-08-26]. Dostupné na internete: <http://arxiv.org/pdf/astroph/0308418v1.pdf>

GARRIGA, J., MUKHANOV, V. F., OLUM, K. D., VILENKIN, A. 2000. Eternal inflation, black holes, and the future of civilizations. [cit. 2012-08-26]. Dostupné na internete: <http://arxiv.org/pdf/astro-ph/9909143v3.pdf>

GINDILIS, L. M., PANOVKIN, B. N. 1979. Metodologija ocenki čisla vnezemnych civilizacij. In KAZJUTINSKIJ, V. V., GINDILIS, L. M., MICKEVIČ, I. V., SAČKOV, J. V., URSUL, A. D. (eds.). Astronomija, metodologija, mirovozrenie. Moskva: Nauka 1979. $400 \mathrm{~s}$.

GONZALES, G., BROWNLEE, D., WARD, P. D. 2002. Zelený pás v Mliečnej ceste. In Kozmos, roč. 32, 2002, č. 1. ISSN 0323-049X, s. 3-6.

GREENE, B. 2001. Elegantní vesmír. Superstruny, skryté rozměry a hledání finální teorie. Praha: Mladá fronta 2001. 400 s. ISBN 80-204-0882-7.

GRYGAR, J. 1997. Vesmír, jaký je. Současná kosmologie (téměř) pro každého. Praha: Mladá fronta 1997. 224 s. ISBN 80-204-0637-9.

HANSON, R. 1998. Burning the Cosmic Commons: Evolutionary Strategies for Interstellar Colonizations. [cit. 2012-08-26]. Dostupné na internete: <http:/ / hanson.gmu. edu/filuniv.pdf>

HOLUBEC, S. 2009. Sociologie světových systémů. Hegemonie, centra, periferie. Praha: Sociologické nakladatelství 2009. 208 s. ISBN 978-80-7419-014-8.

HORSKÝ, J., NOVOTNÝ, J., ŠTEFANÍK, M. 2004. Úvod do fyzikální kosmologie. Praha: Academia 2004. 224 s. ISBN 80-200-1241-9.

HOWARD, A. W., MARCY, G. W., BRYSON, S. T., JENKINS, J. M., ROWE, J. F., BATALHA, N. M., BORUCKI, W. J., KOCH, D. G., DUNHAM, E. W., GAUTIER III., T. N., VAN CLEVE, J., COCHRAN, W. D., LATHAM, D. W., LISSAUER, J. J., TORRES, G., BROWN, T. M., GILLILAND, R. L., BUCHHAVE, L. A., CALDWELL, D. A., CHRISTENSEN-DALSGAARD, J., CIARDI, D., FRESSIN, F., 
HAAS, M. R., HOWELL, S. B., KJELDSEN, H., SEAGER, S., ROGERS, L., SASSELOV, D. D., STEFFEN, J. H., BASRI, G. S., CHARBONNEAU, D., CHRISTIANSEN, J., CLARKE, B., DUPREE, A., FABRYCKY, D. S., FISCHER, D. A., FORD, E. B., FORTNEY, J. J., TARTER, J., GIROUARD, F. R., HOLMAN, M. J., JOHNSON, J. A., KLAUS, T. C., MACHALEK, P., MOORHEAD, A. W., MOREHEAD, R. C., RAGOZZINE, D., TENENBAUM, P., TWICKEN, J. D., QUINN, S. N., ISAACSON, H., SHPORER, A., LUCAS, P. W., WALKOWICZ, L. M., WELSH, W. F., BOSS, A., DEVORE, E., GOULD, A., SMITH, J. C., MORRIS, R. L., PRSA, A., MORTON, T. D. 2011. Planet occurence within 0,25 AU of solar-type stars from Kepler. [cit. 2012-08-26]. Dostupné na internete: <http://arxiv.org/pdf/ 1103.2541v1.pdf>

JOHANSEN, A., SORNETTE, D. 2001. Finite-time singularity in the dynamics of the world population, economic and financial indices. [cit. 2012-08-26]. Dostupné na internete: <http:// arxiv.org/pdf/cond-mat/0002075v4.pdf>

KENT, A. 2011. Too Damned Quiet? [cit. 2012-08-26]. Dostupné na internte: $<$ http://arxiv. org/pdf/1104.0624v1.pdf>

KIRSHNER, R. P. 2005. Výstřední vesmír. Explodující hvězdy, temná energie a zrychlování kosmu. Praha-Litomyšl: Ladislav Horáček-Paseka 2005. 320 s. ISBN 80-7185-729-7.

KRAUSS, L. M., STARKMAN, G. D. 2004. Universal Limits on Computation. [cit. 2012-08-06]. Dostupné na internete: <http://arxiv.org/pdf/astroph/0404510v2.pdf>

LANDIS, G. A. 1998. The Fermi Paradox: An Approach Based on Percolation Theory. [cit. 2012-08-26]. Dostupné na internete: <http:/ / www.geoffreylandis.com/percolation.htp>

LEGG, S. 2008. Machine Super Intelligence. [cit. 2012-08-26]. Dostupné na internete: <http: / / www.vetta.org/documents/Machine_Super_Intelligence.pdf>

LEGG, S., HUTTER, M. 2007a. A Collection of Definitions of Intelligence. [cit. 2012-0826]. Dostupné na internete: <http:/ / arxiv.org/pdf/0706.3639v1.pdf>

LEGG, S., HUTTER, M. 2007b. Universal Intelligence: A Definition of Machine Intelligence. [cit. 2012-08-26]. Dostupné na internete: <http:/ / www.veta.org/documents/UniversalIntelli gence.pdf> 
LINDE, A. D. 1990. Fizika elementarnych častic i infl'acionnaja kosmologija. Moskva: Nauka 1990. 280 s. ISBN 5-02-014345-6.

LINDE, A., LINDE, D., MEZHLUMIAN, A. 1993. From the Big Bang Theory to the Theory of a Stationary Universe. [cit. 2012-08-26]. Dostupné na internete: <http://arxiv.org/PS_cache/gr-qc/pdf/9306/9306035v3.pdf>

LINEWEAVER, C. H., FENNER, Y., GIBSON, B. K. 2004. The Galactic Habitable Zone and the Age Distribution of Complex Life in the Milky Way. [cit. 2012-08-26]. Dostupné na internete: <http://arxiv.org/ftp/astroph/papers/0401/0401024.pdf>

LLOYD, S. 2000. Ultimate physical limits to computation. [cit. 2012-08-26]. Dostupné na internete: <http://arxiv.org/pdf/quant-ph/9908043v3.pdf>

LLOYD, S. 2001. Computational capacity of the universe. [cit. 2012-08-06]. Dostupné na internete: <http://arxiv.org/pdf/quant-ph/0110141v1.pdf>

MAROČNIK, L. S., MUCHIN, L. M. 1986. Galaktičeskij „pojas žizni“. In MOROZOVA, N. D. (ed.). Prošloje i buduščeje Vselennoj. Moskva: Nauka 1986, s. 151-160.

MUNO, M. P., PFAHL, E., BAGANOFF, F. K., BRANDT, W. N., GHEZ, A., LU, J., MORRIS, M. R. 2004. An overabundance of transient $x$-ray binaries within 1 pc of the galactic center. [cit. 2012-08-26]. Dostupné na internete: <http:/ / arxiv.org/pdf/astro-ph/041 2492.pdf>

NOUN, A., CHYBA, CH. F. 2008. Biotechnology and biosecurity. In BOSTROM, N., ĆIRKOVIĆ, M. M. (eds.). Global Catastrophic Risks. Oxford : University Press 2008. 396 s. ISBN 978-0-19-857050-9, s. 343-363.

PIGNOTTI, L. 1966. Poznávanie človeka. Bratislava: Slovenský spisovatel' 1966. 132 s.

POKORNÝ, Z. 2007. Exoplanety. Najdeme ve vesmíru další Zemi? Praha: Academia 2007. 108 s. ISBN 978-80-200-1510-5.

REBANE, K. K. 1986. Signalizacija meždu civilizaciami i ochrana sredy obitanija. In MUCHIN, L. M., SUČKIN, G. L. (eds.). Problema poiska žizni vo Vselennoj. Moskva: Nauka 1986. 256 s. 
REES, M. 2002. Iba šest' čísel. Skryté sily formujúce podobu vesmíru. Bratislava : Kalligam, 2002. 208 s. ISBN 80-7149-507-7.

ROSSLENBROICH, B. 2009. The theory of increasing autonomy in evolution: a proposal for understanding macroevolutionary innovations. In Biology $\mathcal{E}$ Philosophy, 2009, Vol. 24, Issue 5, s. 623-644. ISSN 0169-3867. [cit. 2012-08-26]. Dostupné na internete: <DOI: 10.1007/s10539-009-9167-9>

RUBCOV, V. V., URSUL, A. D. 1984. Problema vnezemnych civilizacij. Filosofskometodologičeskie aspekty. Kišinev: Štiinca 1984. 264 s.

SAGAN, C. 1998. Kosmos. Praha: Eminent-Knižní klub 1998. 368 s. ISBN 80-8587654-X (Eminent) a 80-7176-727-1 (Knižní klub).

SÁNCHEZ-RON, J. M. 1990. Steady-state cosmology, the arrow of time, and Hoyle and Narlikar's theories. In BERTOTTI, B., BALBINOT, R., BERGIA, S., MESSINA, A. (eds.). Modern cosmology in retrospect. Cambridge: University Press 1990. 426 s. ISBN 0-521-37213-5, s. 233-243.

SANDBERG, A. 1999. The Physics of Information Processing Superobjects: Daily Life Among the Jupiter Brains. [cit. 2012-08-26]. Dostupné na internete: <http:/ / www.jet.press. org/volume5/Brains2.pdf>

SINGH, S. 2007. Velký třesk. Praha: Argo a Dokořán 2007. 412 s. ISBN 978-80-7203894-7 (Argo) a 978-80-86569-62-8 (Dokořán).

SPERGEL, D. N., VERDE, L., PEIRIS, H. V., KOMATSU, E., NOLTA, M. R., BENNET, C. L., HALPERN, M., HINSHAW, G., JAROSIK, N., KOGUT, A., LIMON, M., MEYER, S. S., PAGE, L., TUCKER, G. S., WEILAND, W. L., WOLLACK, E., WRIGHT, E. L. 2003. First Year Wilkinson Microwave Anisotropy Probe (WMAP) Observations: Determination of Cosmological Parameters. [cit. 2012-0826]. Dostupné na internete: <http:/ / arxiv.org/pdf/ astro-ph/0302209v3.pdf>

STANKO, V. 1989. Úrovne živého a dialektika. In Filozofia, roč. 44, 1989, č. 6. ISSN 0046-385 X, s. 710-723.

STEINHARDT, P. J., TUROK., N. 2009. Bez počátku a konce. Nová historie vesmíru. Praha - Litomyšl: Ladislav Horáček - Paseka 2009. 268 s. ISBN 978-80-7185-967-3.

STRUGACKIJ, A., STRUGACKIJ, B. 1985. Piknik u cesty. Praha: Mladá fronta 1985. $144 \mathrm{~s}$. 
TAINTER, J. A. 2009. Kolapsy složitých společností. Praha: Dokořán 2009. 320 s. ISBN 978-80-7363-248-9.

TEILHARD DE CHARDIN, P. 1990. Vesmír a lidstvo. Praha: Vyšehrad 1990. 272 s. ISBN 80-7021-043-5.

TEJLER, R. J. 1981. Galaktiki: strojenie i evolucija. Moskva: Mir 1981. 224 s.

TROICKIJ, V. S. 1981. K voprosu o naselennosti Galaktiki. In Astronomičeskij žurnal, roč. 58, 1981, č. 5. ISSN 0004-6299, s. 1121-1130.

TURČIN, A. 2008. Structure of the Global Catastrophe. Moscow : Russian Transhumanist Movement, 2008. [cit. 2012-08-26]. Dostupné na internete: <http://www.scribd.com/doc/ 6250354/STRUCTURE-OF-THE-GLOBALCATASTROPHE-Risks-of-human-extinction-in -the-XXI-century->

URMANCEV, J. A. 1988. Obščaja teorija sistem: sostojanie, priloženija i perspektivy razvitija. In TJUCHTIN, V. S., URMANCEV, J. A. (eds.). Sistema. Simmetrija. Garmonija. Moskva: Mysl' 1988. 320 s. ISBN 5-244-00190-6, s. 38-127.

VIDAL, C. 2010. Black Holes: Attractors for Intelligence? [cit. 2012-08-26]. Dostupné na internete: <http://arxiv.org/ftp/arxiv/papers/1104/1104.4362.pdf>

VILENKIN, A. 2008. Mnoho světů v jednom. Praha-Litomyšl: Ladislav Horáček Paseka 2008. 232 s. ISBN 978-80-7185-936-9.

VINGE, V. 1993. The Coming Technological Singularity: How to Survive in the PostHuman Era. [cit. 2012-08-26]. Dostupné na internete: <http://wwwrohan.sdsu.edu/faculty/vinge/ misc/singularity.html>

WARD, P. D., BROWNLEE, D. 2003a. Rare Earth. Why Complex Life is Uncommon in the Universe. New York: Copernicus 2003. 335 s. ISBN 0-387-95289-6.

WARD, P. D., BROWNLEE, D. 2003b. The Life and Death of Planet Earth. How the New Science of Astrobiology Charts the Ultimate Fate of Our World. New York: Henry Holt 2003. 241 s. ISBN 0-8050-6781-7.

WEBB, S. 2002. If the universe is teeming with aliens... where is everybody? Fifty solutions to the Fermi paradox and the problem of extraterrestrial life. New York: Copernicus 2002. 288 s. ISBN 0-387-95501-1. 
WILEY, K. B. 2011. The Fermi Paradox, Self-Replicating Probes, and the Interstellar Transportation Bandwith. [cit. 2012-08-26]. Dostupné na internete: <http:/ / arxiv.org/pdf/ 1111.6131v1pdf.>

WILLIAMS, D. M. 1998. The Stability of Habitable Planetary Environments. [cit. 201208-26]. Dostupné na internete: <http://www.obspm.fr/encycl/papers/williamsthesis.pdf $>$

YUDKOWSKI, E. 2002. Levels of Organization in General Intelligence. [cit. 2012-0826]. Dostupné na internete: <http:/ / singularity.org/upload/LOGI/ / LOGI.pdf>

ZINNECKER, H. 2003. Chances for earth-like planets and life around metal-poor stars. [cit. 2012-08-26]. Dostupné na internete: <http://arxiv.org/pdf/astroph/0301080.pdf>

ZUBKOV, I. F. 1981. Problém geologickej formy pohybu hmoty. Bratislava: Pravda 1981. $272 \mathrm{~s}$. 


\section{E-LOGOS}

ELECTRONIC JOURNAL FOR PHILOSOPHY

Ročník/Year: 2012 (vychází průběžně/ published continuously)

Místo vydání/Place of edition: Praha

ISSN 1211-0442

Vydává/Publisher:

Vysoká škola ekonomická v Praze / University of Economics, Prague

nám. W. Churchilla 4

Czech Republic

13067 Praha 3

IČ: 61384399

Web: http://e-logos.vse.cz

Redakce a technické informace/Editorial staff and technical information:

Miroslav Vacura

vacuram@vse.cz

Redakční rada/Board of editors:

Ladislav Benyovszky (FHS UK Praha, Czech Republic)

Ivan Blecha (FF UP Olomouc, Czech Republic)

Martin Hemelík (VŠP Jihlava, Czech Republic)

Angelo Marocco (Pontifical Athenaeum Regina Apostolorum, Rome, Italy)

Jozef Kelemen (FPF SU Opava, Czech Republic)

Daniel Kroupa (ZU Plzeň, Czech Republic)

Vladimír Kvasnička (FITT STU Bratislava, Slovak Republic)

Jaroslav Novotný (FHS UK Praha, Czech Republic)

Jakub Novotný (VŠP Jihlava, Czech Republic)

Ján Pavlík (editor-in-chief) (VŠE Praha, Czech Republic)

Karel Pstružina (VŠE Praha, Czech Republic)

Miroslav Vacura (executive editor) (VŚE Praha, Czech Republic) 